This item was submitted to Loughborough's Research Repository by the author.

Items in Figshare are protected by copyright, with all rights reserved, unless otherwise indicated.

\title{
Mid- to late Holocene geomorphological and hydrological changes in the south Taihu area of the Yangtze delta plain, China
}

PLEASE CITE THE PUBLISHED VERSION

https://doi.org/10.1016/j.palaeo.2018.03.012

\section{PUBLISHER}

(C) Elsevier

\section{VERSION}

AM (Accepted Manuscript)

\section{PUBLISHER STATEMENT}

This work is made available according to the conditions of the Creative Commons Attribution-NonCommercialNoDerivatives 4.0 International (CC BY-NC-ND 4.0) licence. Full details of this licence are available at: https://creativecommons.org/licenses/by-nc-nd/4.0/

\section{LICENCE}

CC BY-NC-ND 4.0

\section{REPOSITORY RECORD}

Chen, Ting, David Ryves, Zhanghua Wang, Jonathan Lewis, and Xuening Yu. 2019. "Mid- to Late Holocene Geomorphological and Hydrological Changes in the South Taihu Area of the Yangtze Delta Plain, China". figshare. https://hdl.handle.net/2134/32548. 
Ting Chen ${ }^{\mathrm{a}, \mathrm{b}}$, David B. Ryves ${ }^{\mathrm{c}}$, Zhanghua Wang ${ }^{\mathrm{a}}$, Jonathan P. Lewis ${ }^{\mathrm{c}}$, Xuening $\mathrm{Yu}^{\mathrm{a}}$

6 University, Shanghai 200062, China

Science and Technology, Shenzhen 518055, China

${ }^{c}$ Centre for Hydrological and Ecosystem Science, Department of Geography, Loughborough University, Loughborough LE11 3TU, UK cultivation during this period, however, have not been fully understood for this coastal lowland, which is highly sensitive to sea-level change. To improve understanding of the morphological and hydrological context for evolution of prehistoric rice 
agriculture, two sediment cores (DTX4 and DTX10) in the East Tiaoxi River Plain, south Taihu Plain, were collected, and analysed for radiocarbon dating, diatoms, organic carbon and nitrogen stable isotopes $(\delta 13 \mathrm{C}$ and $\delta 15 \mathrm{~N})$, grain size and lithology. These multiproxy analyses revealed that prior to ca. 7500 cal. yr BP, the East Tiaoxi River Plain was a rapidly aggrading high-salinity estuary (the Palaeo-Taihu Estuary). After ca. 7500 cal. yr BP, low salinity conditions prevailed as a result of strong Yangtze freshwater discharge. Subsequently, seawater penetration occurred and saltmarsh developed between ca. 7000 and 6500 cal. yr BP due to accelerated relative sea-level rise. This transgression event influenced a large area of the Taihu Plain during the Holocene, as shown by multiple sediment records from previous studies. Persistent freshwater marsh (or subaerial land) formed due to dramatic shrinkage/closure of the Palaeo-Taihu Estuary after ca. 5600 cal. yr BP when sea level was relatively stable. We speculate that morphological and hydrological changes of the East Tiaoxi River Plain played an important role in agricultural development across the Taihu Plain during the Neolithic period. The closure of the Palaeo-Taihu Estuary and the formation of stable freshwater marsh (or subaerial land) after ca. 5600 cal. yr BP were critical preconditions encouraging the rapid rise of rice productivity in the Liangzhu period (5500-4500 cal. yr BP). This development changed the landscape and river systems, and thus provided adequate freshwater supply to the Taihu Plain.

\section{Key words}

Coastal wetland; Salinity; Sea level; Freshwater resource; Rice agriculture, 49

\section{Introduction}


The lower Yangtze valley, East China is one of the centres where intense rice growth started in the Neolithic period (Zong et al., 2007; Liu and Chen, 2012). Many studies have been focused on the origin and domestication of rice farming in this region during the Neolithic cultural period (Zong et al., 2007; Mo et al., 2011; Liu and Chen, 2012). The first evidence of collection and consumption of wild rice (ca. 9000-10000 cal. yr BP) was found at Shangshan site, in Zhejiang Province (Liu and Chen, 2012; Zuo et al., 2017). Evidence for rice cultivation also found at the Kuahuqiao site at ca. 7700 cal. yr BP (Zong et al., 2007). Although marine inundation caused by sea-level rise brought rice cultivation to an end at the Kuahuqiao site at ca. 7500 cal. yr BP (Zong et al., 2007), rice farming subsequently expanded to the south of the Hangzhou Bay and in the Taihu Plain, north of Hangzhou Bay (Chen et al., 2008; Zong et al., 2012a; Zheng et al., 2012). Rice domestication started during the period of the Majiabang culture (7000-5800 cal. yr BP), the first Neolithic culture that appeared on the Taihu Plain, though this society still relied mostly on hunting, fishing and gathering (Cao et al., 2006; Fuller et al., 2007; Mo et al., 2011; Zong et al., 2012a; $\mathrm{Xu}, 2015)$. More rice cultivation was practiced during the Songze period (5800-5500 cal. yr BP), but hunting, fishing and gathering were still important at that time (Cao et al., 2006; Mo et al., 2011). Subsequently, rice farming intensified and its yield increased dramatically during the Liangzhu culture (5500-4500 cal. yr BP) (Fan, 2011;

71 quantities of carbonised rice were found at several Liangzhu sites (Fan, 2011), one of which even reached to tens of thousands of kilograms; numerous specialised fine 73 stone tools used for rice farming, such as ploughs and sickles, were also found (Mo et 74 al., 2011). Relying on rapid advances in rice farming, the Liangzhu culture developed into a sophisticated and complex society and was considered as one of the most 
advanced Neolithic societies in the world (Jiang and Liu, 2006; Zhu, 2006; Lawler, 2009; Mo et al., 2011; Zong et al., 2012a; Zhuang et al., 2014).

Several studies suggested that a warm/humid climate promoted the development of rice farming in the lower Yangzte delta (Yu et al., 2000; Chen et al., 2005; Innes et al., 2009, 2014; Patalano et al., 2015), together with ancient people's successful water and landscape management of rice paddies (Zong et al., 2007; Zhuang et al., 2014). Recently, more attention has been paid to the role of the hydrological environment, which is the result of a complex of sea-level, climate and geomorphological conditions (Zong et al., 2007; Qin et al., 2011; Zheng et al., 2012; Long et al. 2014; Patalano et al., 2015). For example, Zong et al. (2007) found that freshwater low-land swamps at the Kuahuqiao site were selected by Neolithic people for rice cultivation. Qin et al. (2011) reported that rice-based agriculture occurred during two intervals of lower salinity, between ca. 7850-7210 cal. yr BP and ca. 3000-2290 cal. yr BP. Although these studies of hydrological background based on individual cores provided insights into our understanding of the development of rice farming in the lower Yangtze valley, new studies on key sites allowing an integrated analysis of previous studies are still required to provide a more detailed environmental context on a regional scale.

We focus here on the hydrological changes during the mid- to late-Holocene in the East Tiaoxi River Plain, part of the southern Taihu Plain (Fig. 1A and 1B). The East Tiaoxi River Plain is a critical part of the Taihu plain, because it was a palaeo-incised valley during the Last Glacial Maximum (LGM) and was occupied by the Palaeo-Taihu Estuary during the early- to mid-Holocene (Fig. 1C; Hong, 1991). Through this estuary, sea water could have reached the centre of the Taihu Plain, and freshwater from the west uplands, which flows into the Taihu lake at present, instead was discharged into Hangzhou Bay (Hong, 1991). Such hydrologic conditions had 
102 restricted the freshwater resource for Neolithic people in the Taihu Plain.

103 Morphological and hydrological changes within the East Tiaoxi River Plain from the

104 Mid-Holocene are therefore potentially critical to understanding the evolution of rice

105 farming in the Taihu Plain over the Neolithic period.

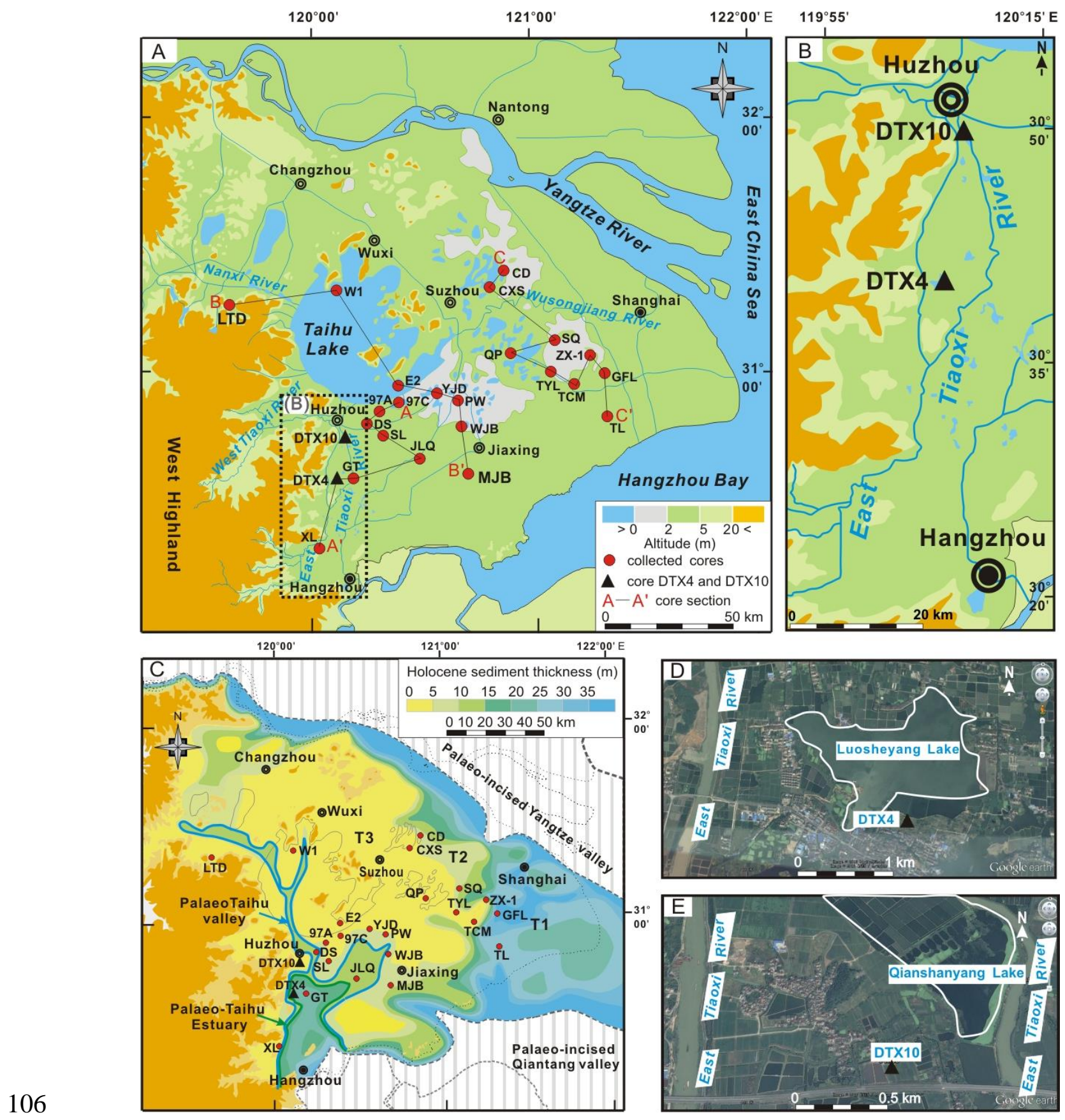

107 
Fig. 1 Maps of the Taihu Plain and location of study sites. (A) Map of the present Taihu Plain (after Song et al., 2013), showing geomorphology, hydrology and locations of core DTX4 and DTX10, and

110 cores collected from previous studies (red solid circles; references in supplementary Table 1). (B) Map

111 of the East Tiaoxi River Plain, including West and East Tiaoxi River and locations of cores DTX4 and

112 DTX10. (C) Palaeotopographical map of the Taihu Plain during the Last Glacial Maximum (after Wang

113 et al., 2012), showing the Palaeo-Taihu valley (blue solid line) and Palaeo-Taihu Estuary (green solid

114 line). (D) and (E) Remote sensing image in 2016, around Luosheyang Lake and Qianshanyang Lake

115 from Google Earth, showing part of East Tiaoxi River and locations of core DTX4 and DTX10,

116 respectively.

118 A complete understanding of the evolution of morphological and hydrological 119 environments of the East Tiaoxi River Plain during the mid- to late-Holocene, 120 however, has been hampered by a lack of high-quality sediment archives with reliable 121 dating allowing detailed sedimentological analysis. To address this gap and fulfill the 122 research aim mentioned above, two sediment cores (DTX 4 and DTX10), spanning 123 the last 7100 and 7600 years respectively, were collected beside the Luosheyang Lake 124 and the Qianshanyang Lake in the East Tiaoxi River Plain in 2014 (Fig. 1). Using 125 these two cores, we studied the past morphological and hydrological environments of 126 the East Tiaoxi River Plain over the last 7600 years, by using a multi-proxy approach 127 including lithology, grain size, diatom analysis and organic geochemistry (including 128 stable isotopes of carbon and nitrogen: $\left.\delta^{13} \mathrm{C}, \delta^{15} \mathrm{~N}\right)$. Additionally, we compared these 129 new results with the hydrological environment inferred from other parts of the Taihu 130 Plain from previously studied cores (Itzstein-Davey et al., 2007; Atahan et al., 2008; 131 Zong et al., 2011, 2012b; Wang et al., 2012; Innes et al., 2014; Liu et al., 2015). Based 132 on these results, we discuss how changing morphological and hydrological conditions 
133 in the East Tiaoxi River Plain influenced the expansion of rice cultivation in the Taihu

134 Plain over the Neolithic period.

\section{Study area and site description}

During the LGM, the landscape of the Taihu Plain was characterised by a series

138 of river terraces (T1, T2 and T3) and incised valleys (Fig. 1C) cutting through these terraces (Yan and Huang, 1987; Li et al., 2000, 2002; Wang et al., 2012). The terraces

$140 \mathrm{~T} 1, \mathrm{~T} 2$ and T3 were regions where the thickness of Holocene sediments were at 20-30

141 m, 5-15 m, and < 5 m, respectively (Yan and Huang, 1987; Li et al., 2000, 2002;

142 Wang et al., 2012). The largest two of these palaeo valleys were the Yangtze valley in

143 the north and the Qiantang valley in the south. The Palaeo-Taihu valley lay along the

144 western highlands, and freshwater discharge from western mountains flowed through

145 it southwards into the Palaeo-Qiantang valley (Yan and Huang, 1987; Hong, 1991;

146 Wang et al., 2012). When sea level rose from $-18 \mathrm{~m}$ to $-4 \mathrm{~m}$ between ca. $8600 \mathrm{cal}$. yr

147 BP and ca. 7300 cal. yr BP, the south part of the Palaeo-Taihu valley became an 148 estuary, allowing sea water from Hangzhou Bay to reach the central Taihu Plain

149 (Hong, 1991; Wang et al., 2012).

150 Present-day geomorphological and hydrological conditions of the Taihu Plain,

151 however, are dramatically different. Today, the Taihu Plain is characterised by a 152 saucer-like depression, in the centre of which lies Taihu Lake (Fig. 1A), the third 153 largest freshwater lake in China. Taihu Lake receives freshwater inflows (e.g. the East 154 and West Tiaoxi Rivers; Fig. 1A) from the mountainous areas to the west of the Taihu

155 Plain and provides an important freshwater resource for the human population in the 156 Taihu Plain.

157 The East Tiaoxi River Plain is the southern part of the Taihu Plain and lies 158 between Taihu Lake in the north and the Qiantang River/Hangzhou Bay in the south 
159 (Fig. 1A and 1B). Relief is slightly higher $(2-5 \mathrm{~m})$ in the south and east, and lower (<

$1602 \mathrm{~m}$ ) in the depression near Taihu Lake. The East Tiaoxi River, the largest river in the

161 East Tiaoxi River Plain, flows northward into Taihu Lake after joining with the West

162 Tiaoxi River in the city of Huzhou.

163 Luosheyang Lake and Qianshanyang Lake are located near the East Tiaoxi River

164 (Fig. 1B, 1D and 1E), and are about $140 \mathrm{~km}$ west of Shanghai. They are both naturally

165 open, shallow ( $<2 \mathrm{~m}$ maximum depth) and flat-bottomed freshwater lakes, through

166 which the East Tiaoxi River and its tributaries flow. Over recent decades, the area of

167 the Luosheyang Lake has been reduced due to extensive marginal development for

168 agriculture (e.g. rice paddies) to about $1.56 \mathrm{~km}^{2}$, while the Qianshanyang Lake has 169 been almost completely reclaimed.

170

\section{3. Material and methods}

172

173

174 May 2014 using a gouge corer (Eijkelkamp Company, the Netherlands), with a 175 diameter of $3 \mathrm{~cm}$. Core DTX4 $\left(30^{\circ} 38^{\prime} 16.465^{\prime \prime} \mathrm{N}, 120^{\circ} 05^{\prime} 28.546^{\prime \prime} \mathrm{E}\right)$ was collected

176 from a reclaimed agricultural field which was previously the edge of the Luosheyang

177 Lake, and core DTX10 from a rice paddy near present Qianshanyang Lake (Fig. 1B,

$1781 \mathrm{D}$ and 1E). Lithology of both cores was examined carefully during the drilling, 179 including particle composition, structure, colour, and presence of plant macrofossils.

180 Recent cultural sediments at the top of each core were removed (the uppermost $80 \mathrm{~cm}$ 181 at DTX4 and $20 \mathrm{~cm}$ at DTX10). Ten plant macrofossils (excluding root material) and 182 organic-rich samples from the two cores were dated via $\mathrm{AMS}{ }^{14} \mathrm{C}$ dating by Beta 183 Analytic, USA (Table 1). All conventional dates were calibrated using the INTCAL 13 
184 database (Talma and Vogel, 1993; Reimer et al., 2009) and calibrated dates with two

185 sigma were presented as 'medial point ages \pm standard deviation' (Table 1). A linear

186 interpolation method was used to construct the age-depth model, using the program

187 'Clam' with 10,000 iterations (Blaauw, 2010; Fig. 2). The sedimentation rate (SR), the

188 best estimated age and the minima and maxima of age confidence intervals were

189 calculated every $2 \mathrm{~cm}$ (core DTX4) and $4 \mathrm{~cm}$ (DTX10) simultaneously, using the

190 'Clam' program. In addition, , a sedimentation hiatus was identified in core DTX10 at

191 a sediment depth of $1.0 \mathrm{~m}$ due to a leaching structure indicative of pedogenesis

$192(0.88-1.0 \mathrm{~m})$.

193

194 Table 1 AMS ${ }^{14} \mathrm{C}$ dating results of core DTX4 and DTX10 195

\begin{tabular}{|c|c|c|c|c|c|c|c|}
\hline $\begin{array}{l}\text { Core } \\
\text { name }\end{array}$ & $\begin{array}{c}\text { Depth } \\
\text { (m) }\end{array}$ & Dated material & $\begin{array}{l}\delta^{13} \mathrm{C} \\
(\%)\end{array}$ & $\begin{array}{c}\text { Conventional } \\
\text { age (yr BP) }\end{array}$ & $\begin{array}{c}\text { Calibrated age } \\
\text { (2 sigma, cal. yr BP) }\end{array}$ & $\begin{array}{c}\text { Median } \\
\text { Calibrated age } \\
\text { (cal. yr BP) }\end{array}$ & Lab. code \\
\hline \multirow[t]{6}{*}{$\begin{array}{c}\text { Core } \\
\text { DTX4 }\end{array}$} & 1.21 & Plant fragments & -27.2 & $1610 \pm 30$ & $1560-1410$ & $1485 \pm 75$ & Beta-383485 \\
\hline & 1.45 & Plant fragments & -28.8 & $940 \pm 30$ & $930-785$ & $858 \pm 73$ & Beta-406458 \\
\hline & 1.81 & Plant fragments & -27.8 & $2860 \pm 30$ & $3065-2920$ & $2993 \pm 73$ & Beta-383486 \\
\hline & 1.91 & Plant fragments & -26.4 & $4680 \pm 30$ & $5575-5550$ & $5562 \pm 13$ & Beta-406459 \\
\hline & 2.5 & Organic-rich mud & -25.7 & $5680 \pm 30$ & $6500-6405$ & $6453 \pm 48$ & Beta-382369 \\
\hline & 5.33 & Plant fragments & NA & $6150 \pm 30$ & $7160-6950$ & $7055 \pm 105$ & Beta-383487 \\
\hline \multirow[t]{4}{*}{$\begin{array}{c}\text { Core } \\
\text { DTX10 }\end{array}$} & 0.88 & Plant fragments & NA & $2720 \pm 30$ & $2870-2760$ & $2815 \pm 55$ & Beta-382371 \\
\hline & 2.3 & Plant fragments & -27.6 & $6650 \pm 30$ & $7580-7480$ & $7530 \pm 50$ & Beta-382366 \\
\hline & 2.91 & Organic-rich mud & -25.1 & $8380 \pm 30$ & $9475-9400$ & $9438 \pm 38$ & Beta-385582 \\
\hline & 4.25 & Plant fragments & -26.1 & $6780 \pm 40$ & $7680-7575$ & $7628 \pm 53$ & Beta-385583 \\
\hline
\end{tabular}




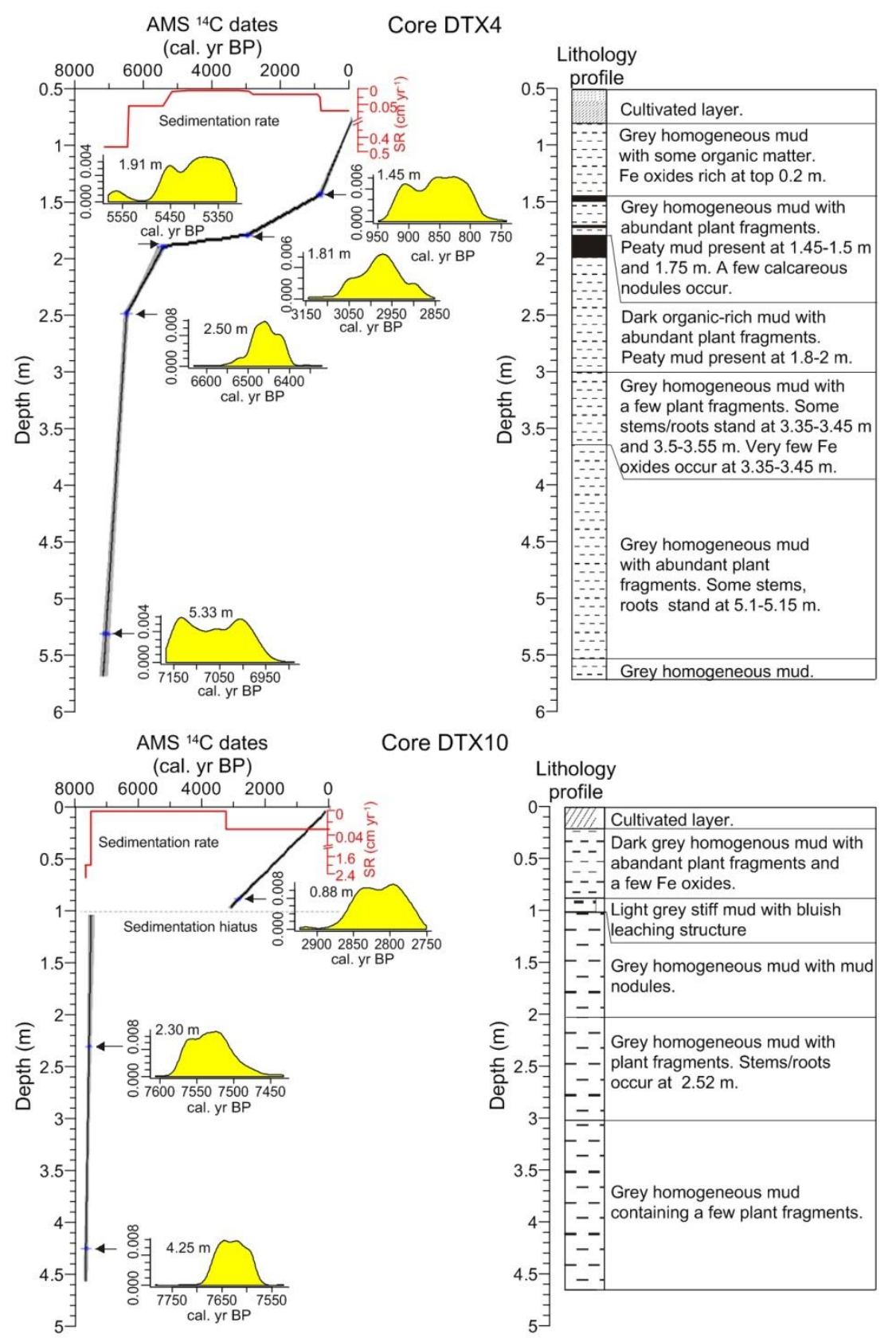

197 Fig. 2 Age-depth model, sedimentation rate (SR) and density distribution of AMS ${ }^{14} \mathrm{C}$ dates (shaded in

198 yellow) basing on the 'Clam' program (Blaauw, 2010), and lithology profile for core DTX4 and

199 DTX10. A sedimentation hiatus was identified at $1.0 \mathrm{~m}$ in core DTX10 because of clear indications of

200 pedogenesis (leaching) apparent in the lithology between $0.88-1.0 \mathrm{~m}$. 
Sediment subsamples were selected at 2 to $10 \mathrm{~cm}$ intervals, using 2 to $5 \mathrm{~cm}$

202 thick slices, with thickness chosen according to sedimentation rate: in core DTX4, 203 every $4 \mathrm{~cm}$ interval ( $4 \mathrm{~cm}$ thick) from $0.8-1.2 \mathrm{~m}, 5 \mathrm{~cm}(5 \mathrm{~cm}$ thick) from $1.2-1.8 \mathrm{~m}, 2$ $204 \mathrm{~cm}(2 \mathrm{~cm}$ thick) from 1.8-2.14 m, $3 \mathrm{~cm}(3 \mathrm{~cm}$ thick) from 2.14-2.5 m, and $10 \mathrm{~cm}(5$ $205 \mathrm{~cm}$ thick) from 2.5-5.7 $\mathrm{m}$; in core DTX10, every $4 \mathrm{~cm}(4 \mathrm{~cm}$ thick) from $0.2-2.3 \mathrm{~m}$, 206 and $10 \mathrm{~cm}(5 \mathrm{~cm}$ thick) from $2.3-4.6 \mathrm{~m}$. A total of 84 and 77 subsamples were 207 obtained for core DTX4 and DTX10 respectively. All subsamples were stored in a 208 fridge at $4{ }^{\circ} \mathrm{C}$ prior to analyses.

\subsection{Diatom analysis}

Diatom concentrations were low in most samples, with a total of only 29 samples

211 in core DTX4 and 10 in core DTX10 containing diatoms at high enough concentration 212 to permit using the standard water bath method (Renberg, 1990; Battarbee et al., 213 2001). Due to extremely low diatom concentrations, 8 samples in core DTX4 and 19 214 in core DTX10, were treated with heavy liquid separation (sodium polytungstate, SPT) 215 using the following procedures (Battarbee and Kneen, 1982; Battarbee et al., 2001). 216 After organic matter and carbonate were removed using hydrogen peroxide $\left(\mathrm{H}_{2} \mathrm{O}_{2}\right)$ 217 and $\mathrm{HCl}$, clay grains were removed by adding a few drops of weak $\mathrm{NH}_{3}$ solution 218 (Battarbee et al., 2001). Then, the non-toxic heavy liquid SPT $\left(3 \mathrm{Na}_{2} \mathrm{WO}_{4} 9 \mathrm{WO}_{3} \cdot \mathrm{H}_{2} \mathrm{O}\right)$ 219 with a density of $2.26 \mathrm{~g} \mathrm{ml}^{-1}$ was used twice to separate diatoms from mineral grains 220 with a density above this. Diatom slides were made in the regular way using the 221 diatom-enriched supernatant taken from the top of SPT solutions, after washing with 222 distilled water. A known number of microspheres were added to all samples to assess 223 diatom concentration (Battarbee and Kneen, 1982). The average number of diatoms 224 counted for samples prepared with regular water-bath and SPT method is 266 and 269 225 valves, respectively, in core DTX4, with the exception of one sample at $5.675 \mathrm{~m}$, for 
226 which only 111 valves were counted due to extremely low diatom concentration. The 227 number of diatoms counted for regularly treated samples was lower in core DTX10 228 than that in core DTX4 due to lower diatom concentration, but counts of at least 174 229 valves were obtained with an average of 192, while for SPT treated samples, over 270 230 valves with an average of 331 were counted. Valves were identified to species level 231 where possible using general (Krammer and Lange-Bertalot, 1986, 1988, 1991a, 232 1991b; http://westerndiatoms.colorado.edu/) and more specialised coastal floras 233 (Witkowski et al., 2000). Diatoms were also classified into their salinity (freshwater, 234 brackish and marine) and habitat preferences (planktonic, benthic), based on the 235 literature and website resources (e.g. van der Wuff and Huls, 1976; Vos and de Wolf, 236 1993; Ryves et al., 2004; http://craticula.ncl.ac.uk/Molten/jsp/; 237 http://www.marinespecies.org/) and ecological knowledge.

238 In most samples some signs of diatom dissolution were apparent: e.g. thinner 239 valve walls in the sub-fossil material. Therefore, the state of dissolution for each valve 240 was recorded and the F-index, the ratio of pristine valves to the sum of pristine and 241 dissolved valves, was calculated for each sample (Ryves et al., 2001). Even where the 242 standard water-bath method was suitable, and diatom concentrations were higher 243 (generally in the fresh water phases), preservation was judged not consistently good 244 enough to support applying a salinity model (which remain robust; Juggins, 2013), as 245 poor preservation is known to cause bias in model outputs (e.g. Ryves et al. 2006, 246 2009). Percentage abundances of diatom data were calculated and plotted using the 247 stratigraphic software package C2 (Juggins, 1991-2009). Diatom zones were 248 determined based on cluster analysis using the CONISS function in the programme 249 Tilia 2.0.41. 


\subsection{Grain size analysis}

251 Grain size analyses were conducted on each subsample. These samples were 252 firstly pretreated with $10 \% \mathrm{H}_{2} \mathrm{O}_{2}$ and then $10 \% \mathrm{HCl}$ to remove organic matter and 253 carbonates respectively, and then washed in distilled water to remove residual $\mathrm{HCl}$. 254 Following this, $5 \mathrm{ml}$ of $5 \%$ Calgon ${ }^{\circledR}$ (sodium hexametaphosphate) was added to each 255 sample before shaking in an ultrasonic bath for 15 minutes to prevent flocculation of 256 fine-grained particles (Beuselinck et al., 1998). Measurements were performed with a 257 Beckman Coulter Laser Diffraction Particle Size Analyzer (LS13320).

\subsection{Measurement of carbon and nitrogen element and their stable isotopes}

259 Samples for total organic carbon (TOC), total nitrogen (TN), $\delta^{13} \mathrm{C}$ and $\delta^{15} \mathrm{~N}$ 260 analysis were firstly freeze-dried, milled and sieved with a $74 \mu \mathrm{m}$ (200 mesh) sieve. 261 The fine fraction was collected and a subsample treated with $1 \mathrm{M} \mathrm{HCl}$ to remove 262 carbonate followed by washing for four to five times with distilled water before 263 drying in an oven at $45{ }^{\circ} \mathrm{C}$. Samples without additional treatment of $\mathrm{HCl}$ were used to 264 measure TC and TN, whilst carbonate-free samples were analysed for TOC and 265 isotopic carbon and nitrogen (Zhang et al., 2007).

266 TC, TOC and TN were measured using an organic element analyzer (Carlo-Erba 267 model EA1110, Italy) in the State Key Laboratory of Marine Geology at Tongji 268 University, China. TOC concentration was calibrated with equation (1) (Yang et al., 269 2011):

$$
\text { TOC }(\%)=\text { TOC }_{\text {measured }}(\%) \times(12-\mathrm{TC}(\%)) /\left(12-\mathrm{TOC}_{\text {measured }}(\%)\right)
$$

271 TOC/TN refers to the weight ratio of TOC $(\%)$ to TN $(\%)$ in this paper. Stable 272 isotopic carbon and nitrogen were measured using a Thermo Deltaplus XL mass 273 spectrometer (continuous flow mode) at the Third Institute of Oceanography, State

274 Oceanic Administration, China. The stable isotopic ratios were expressed as $\delta^{13} \mathrm{C}$ and 
$275 \delta^{15} \mathrm{~N}$, in standard units per mil (\%o), with respect to PeeDee Belemnite (PDB) and 276 atmospheric nitrogen, respectively. The standard samples used for carbon and 277 nitrogen isotope measuring referred to Urea\#2 and Acetanilide\#1 from 278 Biogeochemistry Laboratories Indiana University. The precision for $\delta^{13} \mathrm{C}$ and $\delta^{15} \mathrm{~N}$ 279 were $<0.2 \%$ and $<0.3 \%$, respectively, based on replicated measurements $(n=5)$.

280 TOC/TN ratio and their isotopes are widely used to trace the source of organic 281 matter in lakes and river-estuary-marine systems (Müller and Mathesius, 1999; 282 Meyers, 2003; Wilson et al., 2005; Lamb et al., 2007; Leng and Lewis, 2017). 283 Previous studies have found that TOC/TN ratios are $>12,4-6$, and $<10$ for terrestrial 284 vegetation, bacteria, and algae respectively (in Müller and Mathesius, 1999; Lamb et 285 al., 2007; Leng and Lewis, 2017 and references). $\delta^{13} \mathrm{C}$ values are in a range of -21 to $286-31 \%,-20$ to $-30 \%,-17$ to $-22 \%$ for typical terrestrial $\mathrm{C}_{3}$ plants, freshwater 287 plankton, and marine plankton respectively (Müller and Voss, 1999 and references in; 288 Lamb et al., 2007; Leng and Lewis, 2017 and references in). Terrestrial plants usually 289 have relative low $\delta^{15} \mathrm{~N}$ values compared with aquatic plankton (Thornton and 290 McManus, 1994; Middelburg and Nieuwenhuize, 1998; Müller and Voss, 1999). 291 These values are the underlying principles on which we base our interpretation of 292 TOC/TN, $\delta^{13} \mathrm{C}$ and $\delta^{15} \mathrm{~N}$ profiles in cores DTX4 and DTX10.

2933.5 Collection of previous archive cores and palaeogeographic reconstruction of the 294 Taihu Plain

295 To correlate morphological and hydrological conditions in the East Tiaoxi River 296 Plain to other parts of the Taihu Plain and reconstruct palaeohydrological conditions 297 of the whole Taihu Plain, previously published borehole records were compiled, 298 selecting only those which have good chronological (radiocarbon age) control. In total, 29923 sediment cores were selected and subdivided into 3 sections A-A', B-B' and C-C' 
300 (Fig. 1A and 1C) to make stratigraphic comparisons (core details including location, 301 dating depth, dating material, dating results and references are provided in

302 Supplementary Table 1). Conventional ages in these cores were calibrated in software 303 Calib 7.0 (Talma and Vogel, 1993) using the INTCAL 13 database where dating 304 materials were plant fragments, organic rich mud, seeds, wood and pollen residues, 305 and the Marine 13 database and $\Delta \mathrm{R}$ value of $135 \pm 42$ when dating materials were 306 marine molluscs (Yoneda et al., 2007; Reimer et al., 2013). A linear interpolation 307 method was used to construct ages for key depths, based on the program 'Clam' with 308 10,000 iterations (Blaauw, 2010).

309 Using sedimentary, morphological and hydrological changes obtained in our new 310 cores (DTX10 and DTX4 presented here) together with those inferred in the 23 311 selected existing cores, stratigraphic transections for the sections A-A', B-B' and C-C' 312 were reconstructed. Accordingly, sedimentary morphological and hydrological 313 conditions across the whole Taihu Plain were reconstructed for several periods 314 between ca. 7500 and ca. 5500 cal. yr BP, associated with palaeotopography contexts 315 during the LGM (Fig. 1C; Hong, 1991; Li et al., 2002; Wang et al., 2012) and relative 316 sea-level changes in the Yangtze delta during the Holocene (Zong, 2004; Wang et al., 317 2012, 2013).

\section{Results and interpretation}

4.1 Lithology, AMS ${ }^{14} \mathrm{C}$ dating and sedimentary accumulation rates in cores DTX4 and DTX10

\subsubsection{Core DTX4}

The bottom $2.7 \mathrm{~m}$ of the sequence (i.e. 5.7-3.0 $\mathrm{m}$ depth) consisted of grey 324 homogeneous mud with abundant plant fragments (Fig. 2). This changed to dark, 
organic-rich mud over 3.0-2.0 m, followed by a peaty mud layer (2.0-1.8 m). Grey homogeneous mud with abundant plant fragments reoccurred at 1.8-1.45 m, with 327 peaty mud at 1.75 and $1.5-1.45 \mathrm{~m}$. Plant fragments declined from $1.45 \mathrm{~m}$ to the top. In total, six AMS ${ }^{14} \mathrm{C}$ dates were obtained over the sequence (Table 1). These ages are in reasonable sequential order with the exception of the date obtained at $1.21 \mathrm{~m}$, which is older than the age obtained from the peaty mud at $1.45 \mathrm{~m}$. We reject this reversed age because it could be derived from reworked plant macrofossils. By contrast, the age

332 from peaty mud is more reliable because the peaty mud was formed by in situ 333 deposition of local marsh plants. Stanley (2000) reported that it is quite common that 334 radiocarbon dates of Holocene sediments do not become progressively older with depth in cores from the Yangtze delta, due to the introduction of old carbon during 336 sediment transport and storage. This 'old carbon' phenomenon has also been 337 discussed by Wang et al. (2012). The remaining five dates were used to generate the 338 linear interpolation age-depth model and to calculate sedimentation rate (SR) with the 339 program 'Clam' (Blaauw, 2010; Fig. 2). Relatively high SR of $0.47 \mathrm{~cm}$ per year (cm

$\left.340 \mathrm{yr}^{-1}\right)$ from 7050 to $6450 \mathrm{cal}$. yr BP $(5.33-2.5 \mathrm{~m})$ was followed by a reduced SR of $3410.056 \mathrm{~cm} \mathrm{yr}^{-1}$ from 6450-5560 cal. yr BP (2.5-1.91 m) and $0.004 \mathrm{~cm} \mathrm{yr}^{-1}$ from 342 5560-2990 cal. yr BP (1.91-1.81 m). After 2990 cal. yr BP, SR increased to 0.017 343 from 1.81-1.45 $\mathrm{m}$ and to 0.072 from $1.45-0.8 \mathrm{~m}$ (Fig. 2).

\subsubsection{Core DTX10}

345 From the base of the sequence $(4.7 \mathrm{~m})$ to $1.0 \mathrm{~m}$, lithology was grey 346 homogeneous mud with plant fragments occurring occasionally (Fig. 2). This changed 347 to light grey homogeneous, stiff mud with bluish leaching structures at $1.0-0.88 \mathrm{~m}$, 348 indicating subaerial pedogenesis processes and hence a sedimentation hiatus. At 0.88 $349 \mathrm{~m}$, it became dark, homogeneous mud with abundant plant fragments to the top. Four 
350 AMS ${ }^{14} \mathrm{C}$ dates were obtained throughout the sequence (Table 1). The reversed date at $3512.91 \mathrm{~m}(9475-9400 \mathrm{cal}$. yr BP) was rejected, as we argue that it was also derived from 352 reworked plant material as discussed earlier (Stanley, 2000; Wang et al., 2012). The 353 remaining three dates were used to construct the age-depth model and to calculate SR 354 based on 'Clam' (Fig. 2). When running the age-depth model in 'Clam', a 355 sedimentation hiatus was set at $1.0 \mathrm{~m}$, as reflected by the pedogenesis at $1.0-0.88 \mathrm{~m}$. 356 Core DTX10 showed similar SR pattern to core DTX4. Before 7460 cal. yr BP (below $3571 \mathrm{~m}$ ), SR was high (up to $2 \mathrm{~cm} \mathrm{yr}^{-1}$ ), thereafter pedogenesis and a sedimentation 358 hiatus occurred from 7460 to $2810 \mathrm{cal}$. yr BP (1.0-0.88 m). Following this, SR rose to $3590.03 \mathrm{~cm} \mathrm{yr}^{-1}$ after 2810 cal. yr BP $(0.88-0 \mathrm{~m})$.

$360 \quad 4.2$ Diatom assemblages

$361 \quad 4.2 .1$ Core DTX4

362 A total of 236 species were identified and four habitat groups were distinguished 363 including freshwater, salt-tolerant freshwater, brackish and marine species. No 364 diatoms were found from 2.0-2.75 $\mathrm{m}$ and 1.2-1.45 m. All diatom species $>5 \%$ were 365 plotted as percentages of the total assemblage in Figure 3. 


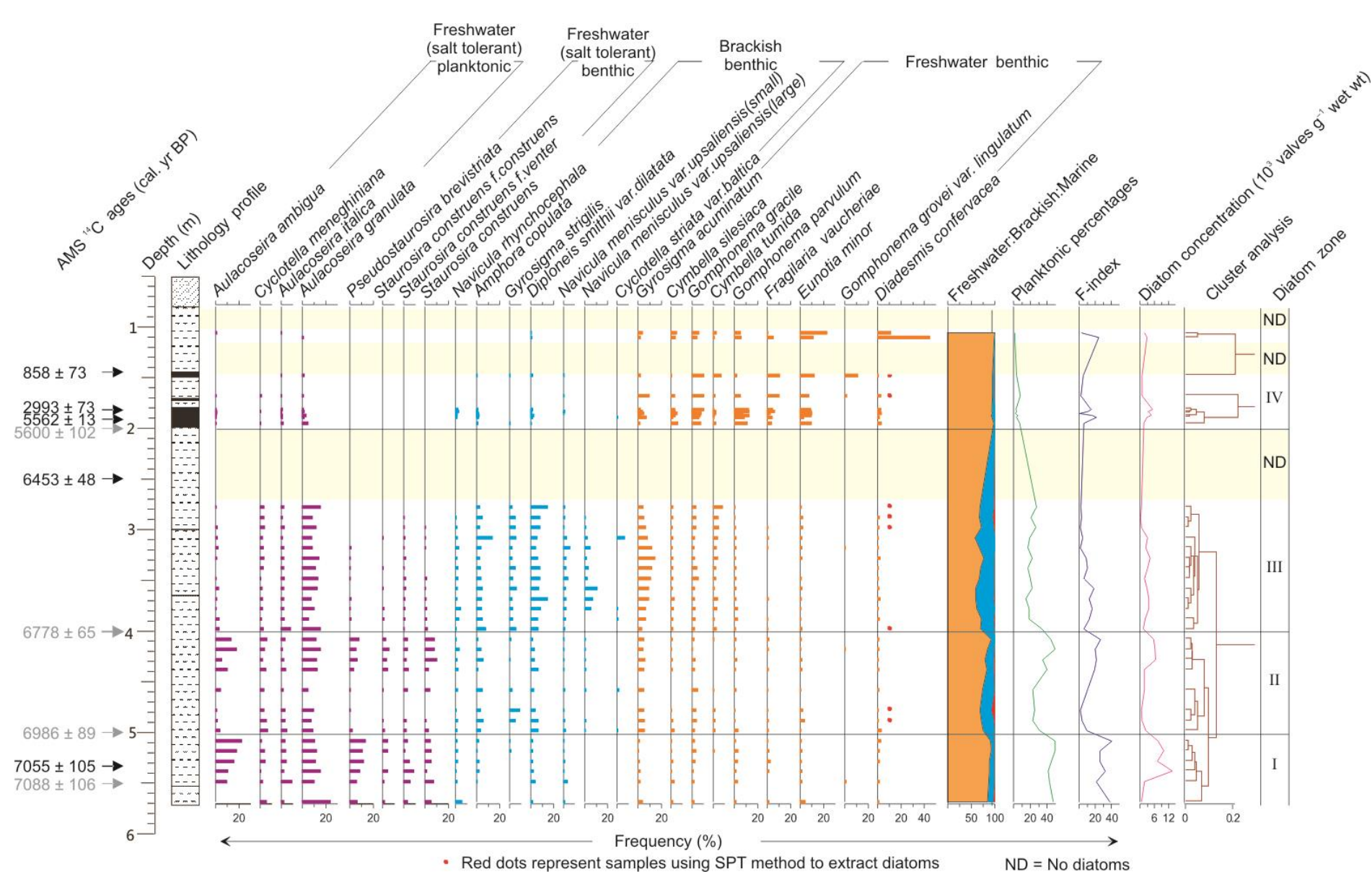

368 Fig. 3 Diatom taxa in core DTX4 (> $5 \%$ relative abundance) separated into freshwater (including both freshwater and salt-tolerant freshwater groups), brackish, and marine species, 369 percentages of planktonic species, F-index and diatom concentration. Calibrated AMS ${ }^{14} \mathrm{C}$ dates (in dark) and calculated age regions (in grey) for important boundaries are presented as 'medial point ages \pm standard deviation', as in Figures 4, 5 and 7. 
In Zone I (5.7-5.0 m, 7140-6990 cal. yr BP), diatom concentration was the 372 highest over the whole sequence (avg. $6.84 \times 10^{3}$ valve $\mathrm{g}^{-1}$ wet weight). On the 373 contrary, F-index was the highest, with $29.1 \%$ of valves on average remaining in 374 pristine state (Fig. 3). The two most abundant species were Aulacoseira granulata 375 (avg. $13.8 \%$ ) and Aulacoseira ambigua (avg. $12.6 \%$ ). These two salt-tolerant 376 freshwater planktonic species with low salt tolerance favour shallow fresh water (low 377 salinity tolerant) and well-mixed hydrological conditions (Kilham, 1990; Owen and 378 Crossley, 1991). Freshwater benthic species such as Pseudostaurosira brevistriata 379 (avg. $9.2 \%$ ), Staurosira construens (avg. $4.9 \%$ ) and its varieties of Staurosira 380 construens f. venter (avg. $4.3 \%$ ) and Staurosira construens f. construens (avg. $2.5 \%$ ) 381 followed. Brackish benthic (e.g. Diploneis smithii var. dilatata, Amphora copulata) 382 and freshwater benthic species (e.g. Gomphonema gracilelparvulum, Eunotia minor) 383 were also found, but at low percentages (less than $3 \%$ for each). The average 384 percentage of freshwater species (including both freshwater and freshwater with low 385 salt tolerance groups) in this section was $88.5 \%$ while brackish species accounted for only $9.9 \%$, and the average percentage of planktonic species was $39.5 \%$.

387 In Zone II (5.0-4.0 m, 6990-6780 cal. yr BP), the diatom concentration decreased 388 to $3.23 \times 10^{3}$ valve $\mathrm{g}^{-1}$ wet weight, while the F-index declined slightly to $13.9 \%$. 389 Relative concentration of freshwater planktonic (e.g. A. ambigua) and freshwater 390 benthic with low salt tolerance species (e.g. P. brevistriata, S. construens and its 391 varieties of $S$. construens f. venter and S. construens f. construens) decreased slightly, 392 with the exception of $A$. granulata which remained fairly constant. Correspondingly, 393 percentages of brackish and freshwater benthic species (including D. smithii var. 394 dilatata, A. copulata, Gyrosigma acuminatum, G. gracile) rose slightly. A brief 395 recovery of the low salinity planktonic (A. ambigualgranulata) and benthic ( $P$. 396 brevistriata, S. construens and its varieties) group occurred at the top of this unit 
(4.0-4.4 m). The average percentages of freshwater species dropped to $78.5 \%$ while brackish species rose to $19.3 \%$, and planktonic species decreased to $29.5 \%$.

In Zone III (4.0-2.7 m, 6780-6500 cal. yr BP), a further drop of diatom concentration (avg. $2.23 \times 10^{3}$ valve $\mathrm{g}^{-1}$ wet weight) occurred, accompanied by 401 increasing dissolution (F-index dropped to $7.9 \%$ ). A. granulata remained relatively 402 abundant (avg. $10.8 \%$ ), despite a further decrease in the low salinity assemblages, 403 giving way to brackish benthic (e.g., D. smithii var. dilatata, A. copulata, Gyrosigma 404 strigilis and Navicula menisculus) and freshwater benthic (e.g. G. accuminatum, G. 405 gracile, Cymbella tumida) species. The average percentage of freshwater species 406 declined to $66.7 \%$ and brackish species rose to $31.6 \%$, with the planktonic group 407 falling to $20.4 \%$.

408 A remarkable shift in the diatom assemblage occurred in Zone IV (2.0 $\mathrm{m}$ from 409 the top, 5570 cal. yr BP to the present), associated with a slight increase in diatom 410 concentration (avg. $2.85 \times 10^{3}$ valve $\mathrm{g}^{-1}$ wet weight) and increase in F-index (avg. $4119.7 \%$ ). This unit was dominated by freshwater benthic and epiphytic species of $G$. 412 parvulum/gracile, E. minor, Fragilaria vaucheriae and Cymbella silesiaca, with 413 very few brackish benthic (e.g. D. smithii var. dilatata, A. copulata, N. menisculus, G. 414 strigilis) and freshwater to low salinity tolerant planktonic species (e.g. A. 415 granulata/ambigua). In the uppermost samples (1.1-1.0 m), Diadesmis confervacea 416 became frequent (up to $45 \%$ ), an indicator of aerial/terrestrial or very shallow-water 417 conditions (Gell et al., 2007). Freshwater species accounted for $95.1 \%$ and brackish 418 species were $<5 \%$ on average, while planktonic species accounted for only $3.9 \%$ of 419 the assemblage. 


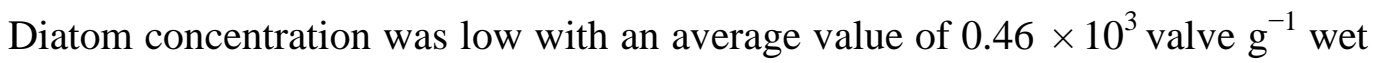
weight for the whole core (Fig. 4), probably resulting from strong dissolution of diatoms reflected by low average F-index value ( $\sim 7.4 \%)$ and dilution caused by high sediment accumulation rates or low diatom productivity. No diatoms were found from 2.7-3.0 $\mathrm{m}$ and 0.84-2.0 $\mathrm{m}$ and only a few broken diatom fragments were found on slides for samples from the top to $0.84 \mathrm{~m}$. Preservation in one sample at $0.66 \mathrm{~m}$ was slightly better, but most remaining diatoms were the dissolved centres of large benthic genera Pinnularia or Cymbella, but which cannot be identified to species level. For other samples from 0.3 to $0.84 \mathrm{~m}$, broken fragments of freshwater genera, such as

430 Eunotia species, were seen. A total of 154 species were identified for the whole 431 sequence and diatom species $>5 \%$ plotted as relative abundance in Figure 4.

432 The diatom assemblage from the base to $2.0 \mathrm{~m}$ (7650-7520 cal. yr BP; except 433 2.7-3.0 $\mathrm{m}$ where no diatoms were found) was dominated by Cyclotella striata (avg. $43422.5 \%$ ), which is usually abundant in river-mouth/estuarine environments (Ryu et al., 435 2005), Actinoptychus senarius (avg. $19.8 \%$ ), the relatively low-salinity coastal 436 planktonic species (Grönlund, 1993; Hasle and Syvertsen, 1996), Paralia sulcata (avg. $4379.3 \%$ ) which is used as a marker for the coastal East China Sea (Tada et al., 1999. 438 Ryu et al., 2005), and Chaetoceros spp. resting spores, typical marine species (avg. $4399.2 \%$ ). Other species found but in relatively low percentage were coastal species of 440 Thalassiosira nanolineata (Grönlund, 1993; Hasle and Syvertsen, 1996) and brackish 441 benthic species such as Diploneis smithii var. dilatata/smithii, Nitzschia granulata, 442 Cocconeis costata var. pacifica. In total, percentages of marine and brackish species 443 were $56.3 \%$ and $37.9 \%$ on average respectively, and planktonic species $77.4 \%$ 444 (including tychoplanktonic taxa). 


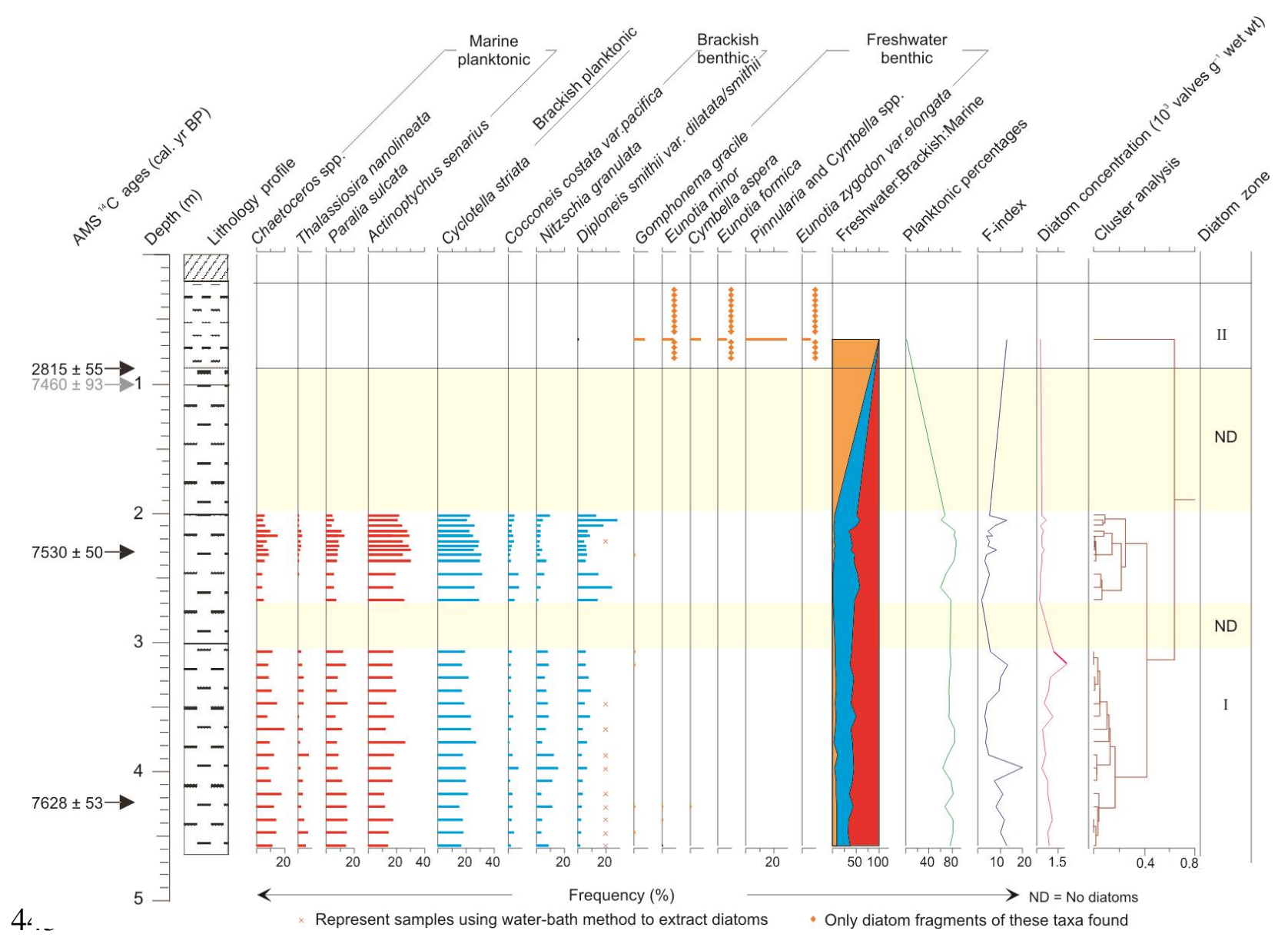

446 Fig. 4 Diatom taxa in core DTX10 (> $5 \%$ relative abundance) with separated into freshwater,

447 brackish and marine species, percentages of planktonic species, F-index and diatom concentration.

449 Although preservation was very poor in samples from the top to $0.84 \mathrm{~m}$, it was 450 clear that the original diatom assemblage was completely different. Almost $99 \%$ of 451 diatom valves (as represented by the sample at $0.66 \mathrm{~m}$ ) belonged to freshwater benthic 452 species (including Gomphonema gracile, Cymbella aspera, Eunotia minor, E. 453 formica and unidentified Pinnularia and Cymbella species). We argue that the switch 454 from a brackish/marine to a freshwater assemblage from Zone I to Zone II reflects a 455 real change to the salinity and hydrology of the system as the vestigial fragments of 456 diatoms in Zone II are resistant and have distinctive morphologies. Had these taxa 
457 been part of the assemblage of earlier sections, they would have been significant 458 aspects of the assemblages there also. By the same token, most of the taxa in the 459 earlier, more marine parts of Zone I are also very resistant to dissolution (e.g. 460 Chaetoceros cysts, Paralia sulcata, Cyclotella striata) with distinctive taphonomic 461 end-members, and would have appeared in Zone I had they been present in the 462 original assemblage in that section. Thus we are confident that Zone I was deposited 463 under brackish-marine conditions while Zone II represents a freshwater system.

\subsection{Grain size, TOC/TN ratio and C-N stable isotopes}

465 Based on grain size composition, TOC, TN, TOC/TN and C-N stable isotope $466\left(\delta^{13} \mathrm{C}, \delta^{15} \mathrm{~N}\right)$ variations, cores DTX4 and DTX10 were divided into five and three 467 zones, denoted as Zone I-V, respectively (Figs 5-7). Zone II and V in core DTX4 (Fig.

4685 ) were both divided into three sub-zones based on variation of TOC/TN ratio, $\delta^{13} \mathrm{C}$ 469 and $\delta^{15} \mathrm{~N}$ values. Zone I and III in core DTX10 were also divided into three and two 470 sub-zones respectively. 


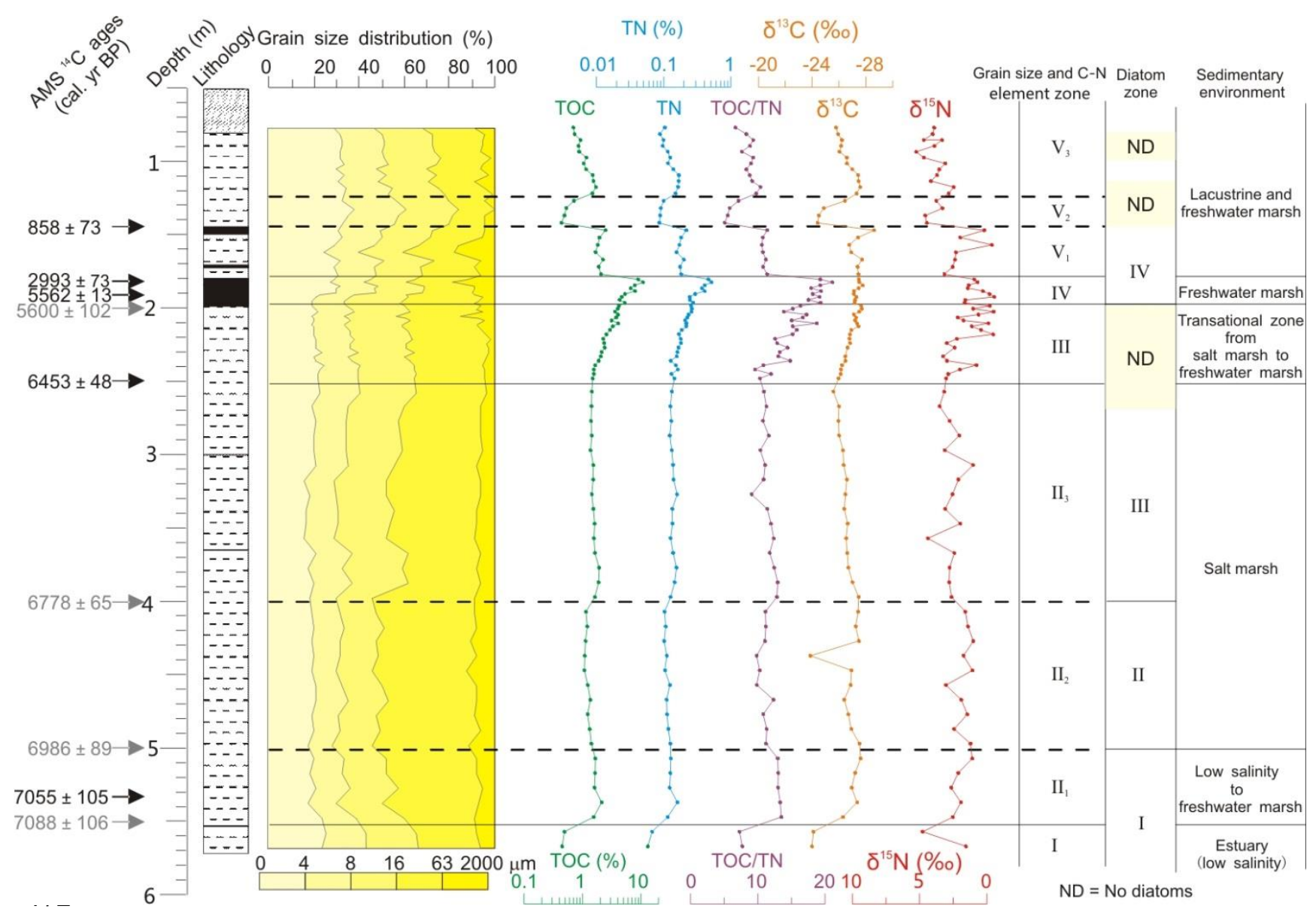

473 Fig. 5 Lithology and sedimentary parameters of core DTX4, including AMS ${ }^{14} \mathrm{C}$ age, grain size

474 distribution, TOC, TN, TOC/TN, $\delta^{13} \mathrm{C}, \delta^{15} \mathrm{~N}$, and interpretation of sedimentary environment.

\subsubsection{Core DTX4}

In Zone I (5.7-5.5 m, 7140-7100 cal. yr BP), clay content $(<4 \mu \mathrm{m})$ was around $47724.8 \%$, silt $(4-63 \mu \mathrm{m}) 67.7 \%$, and sand $(63-2000 \mu \mathrm{m}) 7.3 \%$ on average. In Zone II 478 (5.5-2.5 m, 7100-6450 cal. yr BP), clay content (avg. $19.6 \%$ ) decreased and silt 479 content (avg. $72.7 \%$ ) increased slightly, particularly for grains between 16 and $63 \mu \mathrm{m}$. 480 No change occurred in sand content. Particles between 8-16 $\mu \mathrm{m}$ increased slightly 481 while particles between $16-63 \mu \mathrm{m}$ fell in $\mathrm{II}_{3}(4.0-2.5 \mathrm{~m}, 6780-6450$ cal. yr $\mathrm{BP})$ 482 compared to $\mathrm{II}_{1}\left(5.5-5.0 \mathrm{~m}, 7100-6990 \mathrm{cal}\right.$. yr BP) and $\mathrm{II}_{2}(5.0-4.0 \mathrm{~m}, 6990-6780 \mathrm{cal}$. 
yr BP). Grain size assemblages in Zone III $(2.5-2.0 \mathrm{~m}, 6450-5570$ cal. yr BP) remained similar to those of Zone II, followed by a sudden increase in sand content in Zone IV (2.0-1.8 m, 5570-2990 cal. yr BP) and clay content in Zone V (1.8 $\mathrm{m}$ to the top, 2990 cal. yr BP to the present) with an opposite trend in silt content.

The linear correlation of TOC to TN (Fig. 6A) implied that TN content was controlled mostly by organic matter, while the positive TN intercept of $0.07 \%$ indicated a slight contribution from inorganic nitrogen. Plots of $\delta^{13} \mathrm{C}$ and $\delta^{15} \mathrm{~N}$ against TOC/TN revealed a mixture of freshwater and marine algae and terrestrial $\mathrm{C}_{3}$ plants 491 (Fig. 6B and 6C). In Zone I, TOC (avg. $0.47 \%$ ), TN (avg. $0.06 \%$ ) and TOC/TN (avg. 492 7.48) minima coincided with relatively high $\delta^{13} \mathrm{C}$ (avg. $-24.04 \%$ ) and $\delta^{15} \mathrm{~N}$ (avg. $493+3.16 \%$ ), indicating contribution from marine plankton and bacteria (Müller and 494 Mathesius, 1999; Müller and Voss, 1999; Lamb et al., 2007). The bi-plot of $\delta^{13} \mathrm{C}$ to 495 TOC/TN showed that Zone I samples lay in the domain of marine algae or marine 496 particulate organic carbon (POC; Fig. 6B). The bi-plot of $\delta^{15} \mathrm{~N}$ against TOC/TN 497 reflected a predominant contribution from algae as well (Fig. 6C).

498 An abrupt increase in TOC (1.07-2.12 \%, avg. $1.47 \%)$, TN (0.10-0.16 \%, avg. $4990.13 \%)$ and TOC/TN $\left(9.07-13.50\right.$, avg. 11.53) characterised zone II with lower $\delta^{13} \mathrm{C}$ 500 (from $-25.58 \%$ o to $-26.61 \%$, avg. $-26.74 \%$ ) and $\delta^{15} \mathrm{~N}$ (from $+1 \%$ o to $+4.39 \%$, avg. $501+2.25 \%$ ), signifying the sudden increase in importance of $\mathrm{C}_{3}$ terrestrial plants and 502 reflecting the formation of a marsh environment. A shift on the bi-plots of $\delta^{13} \mathrm{C}$ and $503 \delta^{15} \mathrm{~N}$ vs. TOC/TN implied a mixture of freshwater POC and $\mathrm{C}_{3}$ plants for samples in 504 Zone II with one exception of marine POC in Zone $\mathrm{II}_{2}$. The gradual increase in $\delta^{13} \mathrm{C}$ 505 and $\delta^{15} \mathrm{~N}$ from Zone $\mathrm{II}_{1}$ to $\mathrm{II}_{2}$, and to $\mathrm{II}_{3}$, coincided with changes in position in bi-plots 506 of $\delta^{13} \mathrm{C}$ and $\delta^{15} \mathrm{~N}$ against TOC/TN which was interpreted as a slight, but persistent, 507 increase in the importance of marine algae/POC from the bottom to the top of Zone II. 
Core DTX4
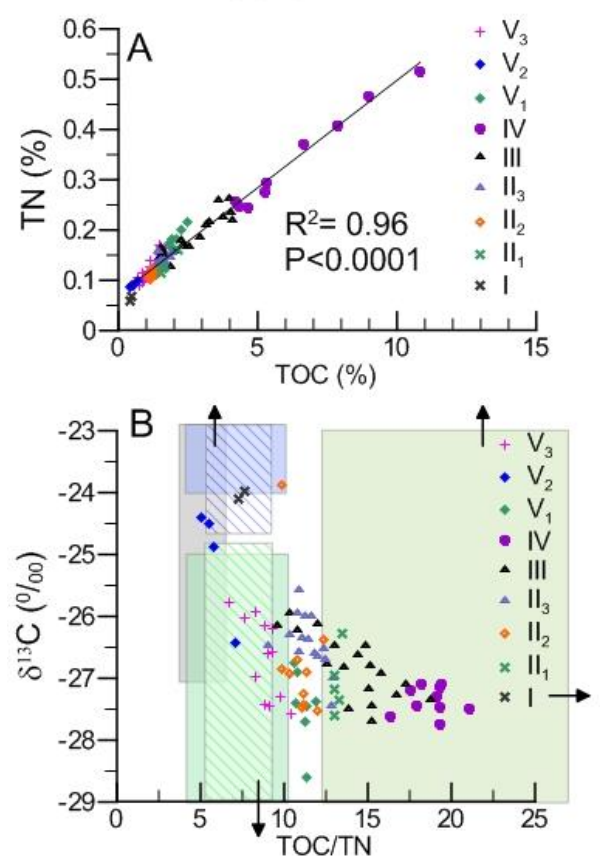

Bacteria

Freshwater POC

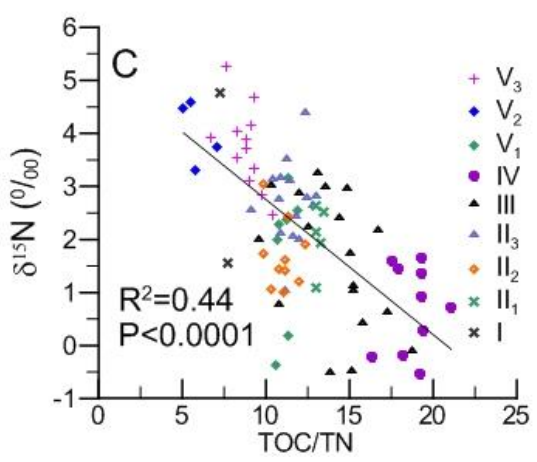

\section{Core DTX10}
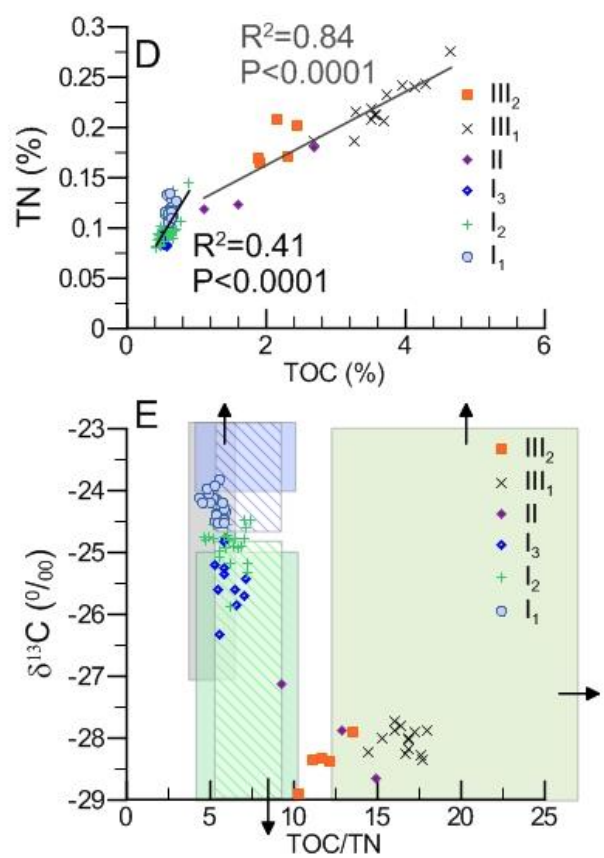

Marine POC

Freshwater algae
Marine algae

C3 terrestrial plants

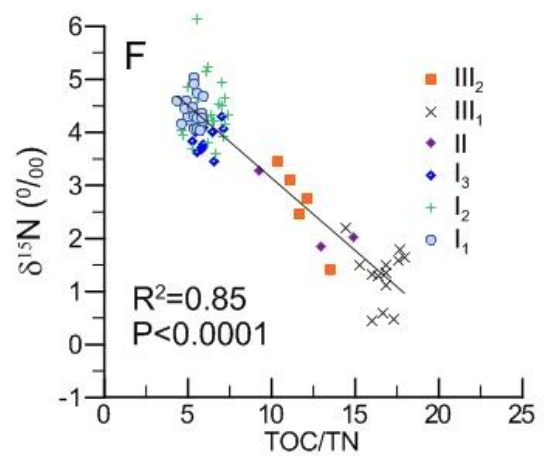

509 Fig. 6 Correlation between TOC and TN (A and D), biplot of $\delta^{13} \mathrm{C}$ values and TOC/TN (B and E), correlation between $\delta^{15} \mathrm{~N}$ values and TOC/TN (C and F) for core DTX4 (A to C) and DTX10 (D to F),

511 respectively. Regions for different type of organic matter are after Lamb et al. (2007).

TOC, TN, TOC/TN values increased gradually to maxima of $10.83 \%, 0.51 \%$

513 and 21.09, respectively, from Zone III to the top of IV where lithology changed to 514 peaty mud, while $\delta^{13} \mathrm{C}$ and $\delta^{15} \mathrm{~N}$ values dropped consistently to minima of $-27.76 \%$ 515 and $-0.55 \%$, respectively. Integrating patterns on the two bi-plots (Fig. 6B and 6C), 
516 Zone III was dominated mostly by terrestrial $\mathrm{C}_{3}$ plants and secondarily by freshwater 517 algae/POC, while typical terrestrial $\mathrm{C}_{3}$ plants dominated the organic matter

518 composition of Zone IV. In Zone V, a rapid drop in TOC (avg. $1.34 \%$ ), TN (avg. $5190.14 \%$ ) and the TOC/TN ratio (avg. 9.13) occurred, with lowest values in subzone $\mathrm{V}_{2}$

520 followed by an increase in subzone $\mathrm{V}_{3}$. The $\delta^{13} \mathrm{C}$ values remained depleted except for 521 subzone $\mathrm{V}_{2}(1.25-1.45 \mathrm{~m})$ where they showed peaks, while the $\delta^{15} \mathrm{~N}$ values increased 522 suddenly and remained high from the bottom to the top. The pattern on the two 523 bi-plots (Fig. 6B and 6C) suggested an increase in freshwater algae/POC and bacteria 524 in Zone $\mathrm{V}$, especially in Zone $\mathrm{V}_{2}$ where algae and bacteria dominated.

\subsubsection{Core DTX10}

In Zone I (from the base to $1.0 \mathrm{~m}, 7650-7460$ cal. yr BP), silt content was 528 50-74 \%, the highest values in the profile, with lesser amounts of clay and sand (Fig. 529 7). Zone II (1.0-0.88 m, 7460-2810 cal. yr BP) was a transitional zone for all proxies.

530 There was a slight and gradual increase in silt content from the bottom to the top, 531 while sand content remained constant. In Zone III ( $0.88 \mathrm{~m}$ to the top, $2810 \mathrm{cal}$. yr BP 532 to present) both silt and clay content dropped while sand content rose dramatically to $53326 \%$ on average, with a slight increase in clay and silt content at the top of Zone $\mathrm{III}_{2}$. 


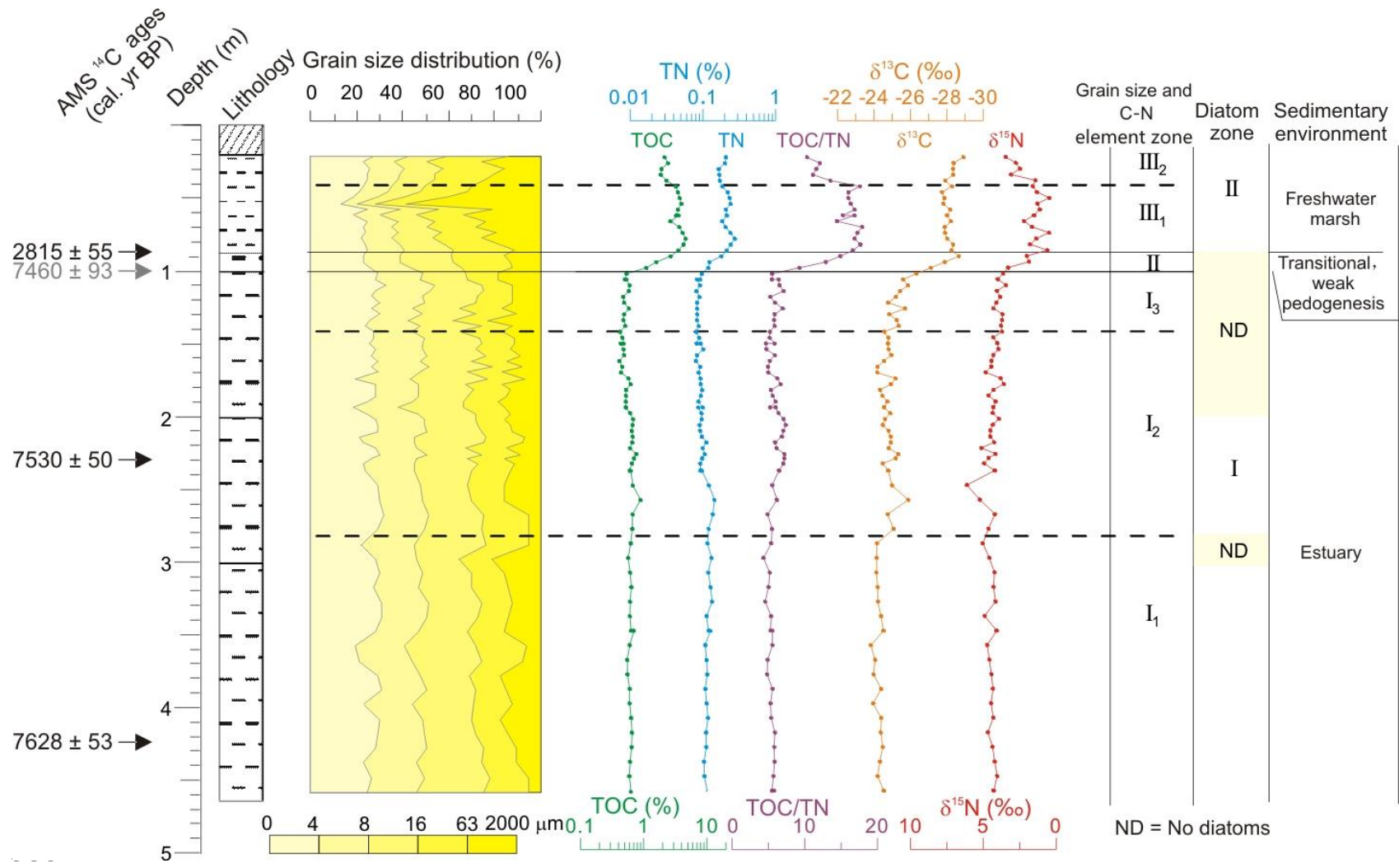

536 Fig. 7. Lithology and sedimentary parameters of core DTX10, including AMS ${ }^{14} \mathrm{C}$ age, grain size

537 distribution, TOC, TN, TOC/TN, $\delta^{13} \mathrm{C}, \delta^{15} \mathrm{~N}$, and sedimentary environments interpretation.

538 A linear correlation between TOC and TN was found, but two discrete groups 539 were identified (Fig. 6D): the samples in Zone I formed one group and samples in

540 Zone II and III a second. This showed that TN values were mostly controlled by 541 organic matter, but also inorganic nitrogen contributed slightly as shown by the 542 positive $\mathrm{TN}$ intercept of $0.035 \%$ and $0.09 \%$ respectively. Plotting $\delta^{13} \mathrm{C}$ against 543 TOC/TN revealed a mixture of two end members of POC/algae/bacteria and $\mathrm{C}_{3}$ 544 terrestrial plants (Fig. 6E). This explanation was supported by the strongly negative 545 linear correlation between $\delta^{15} \mathrm{~N}$ and TOC/TN $(r=-0.85$; Fig. $6 \mathrm{~F})$. TOC values were $546 \quad 0.42-0.89 \%$ (avg. $0.59 \%$ ) in zone I and TN 0.08-0.14 \% (avg. $0.10 \%$ ) (Fig. 7), while 547 TOC/TN ratios were 4.35-7.41 (avg. 5.80). These minimum values were accompanied 
548 by the highest $\delta^{13} \mathrm{C}$ (from $-23.82 \%$ to $-26.32 \%$, avg. $-24.73 \%$ ) and $\delta^{15} \mathrm{~N}$ values 549 (from $+3.44 \%$ o to $+6.12 \%$, avg. $4.30 \%$ ). Very small increases in TOC, TN and

550 TOC/TN coincided with minor decreases of $\delta^{13} \mathrm{C}$ and $\delta^{15} \mathrm{~N}$ from Zone $\mathrm{I}_{1}$ to $\mathrm{I}_{3}$. 551 Integrating patterns on the plots of $\delta^{13} \mathrm{C}$ and $\delta^{15} \mathrm{~N}$ against TOC/TN, a mixture of 552 freshwater and marine algae/POC and bacteria composed the organic matter source 553 for samples in Zone I, with the freshwater algal/POC contribution increasing from 554 Zone $\mathrm{I}_{1}$ to $\mathrm{I}_{3}$. In Zone II, TOC and TN values increased rapidly up to $1.79 \%$ and $0.14 \%$ 555 on average and TOC/TN up to 12.37 . On the contrary, $\delta^{13} \mathrm{C}$ and $\delta^{15} \mathrm{~N}$ declined to $556-27.89 \%$ and $+2.39 \%$, respectively. Changes in all these proxies reflected an abrupt 557 addition of terrestrial organic matter from $\mathrm{C}_{3}$ plants, supported by the bi-plots of $\delta^{13} \mathrm{C}$ 558 and $\delta^{15} \mathrm{~N}$ against TOC/TN. In Zone III, this pattern of consistently high TOC, TN and $559 \mathrm{TOC} / \mathrm{TN}$ and lower $\delta^{13} \mathrm{C}$ and $\delta^{15} \mathrm{~N}$ continued, with small decreases in these 560 parameters in Zone $\mathrm{III}_{2}$. On bi-plots of $\delta^{13} \mathrm{C}$ and $\delta^{15} \mathrm{~N}$ vs. TOC/TN, samples of Zone $561 \mathrm{III}_{1}$ fell in the region typical of $\mathrm{C}_{3}$ terrestrial plants and samples of Zone $\mathrm{III}_{2}$ in the 562 region between $\mathrm{C}_{3}$ plants and freshwater POC/algae.

\section{5. Discussion}

5655.1 Sedimentary, morphological and hydrological changes in the East Tiaoxi River 566 Plain

567 The dominance of marine diatoms and marine algae/POC contribution for the 568 TOC in core DTX10 confirms that there was a high salinity estuary (the Palaeo-Taihu 569 Estuary) in the East Tiaoxi River Plain before ca. 7500 cal. yr BP (Figs 4, 7; Hong, 570 1991), in response to rapid early to mid-Holocene sea-level rise (Chappell and Polach, 571 1991; Bard et al., 1996; Bird et al., 2007; Wang et al., 2012). The high sedimentation 572 accumulation rate up to $2 \mathrm{~cm} \mathrm{yr}^{-1}$ in core DTX10 during this period signified rapid 
573 infilling of this estuary. From ca. 7500 cal. yr BP, freshening occurred at site DTX10

574 indicated by the increase in organic source from freshwater algae/POC (Zone $\mathrm{I}_{2}-\mathrm{I}_{3}$ in

575 Fig. 7). At some time after ca. 7500 cal. yr BP, the area around core DTX10 was

576 subaerially exposed until ca. $2800 \mathrm{cal}$. yr BP, inferred from the sedimentation hiatus

577 and observed pedogenesis (1.0-0.88 $\mathrm{m}$ in Fig. 2 and 7). In contrast, the area around

578 core DTX4 changed from estuary to a low-salinity marsh during ca. 7100-7000 cal. yr

579 BP, indicated by dominant organic matter changing from marine algae/POC to

580 freshwater algae/POC and $\mathrm{C}_{3}$ terrestrial plants (Fig. 5). The estuary at $7100 \mathrm{cal}$. yr BP

581 was also characterised by low salinity, with the diatom assemblages dominated by

582 salt-tolerant freshwater group of A. granulatalambigua, P. brevistriata, S. construens

583 and its varieties of S. construens $f$. venter and S. construens f. construens (Fig. 3).

584 These diatom taxa are often found in isolation basins (e.g. freshwater lakes formed as

585 sea level falls) (Stabell, 1985), and therefore, their high concentrations indicate that

586 the site DTX4 was in the stage of isolation from seawater during ca. 7100-7000 cal. yr

587 BP. Consequently, we infer that the freshening of the East Tiaoxi River Plain likely

588 started between 7500-7100 cal. yr BP, possibly due to coastal development and

589 freshwater discharge from the Yangtze River, benefitting from a warmer and, more

590 importantly, wetter climate during the Holocene Thermal Maximum (Wang et al.,

591 2005). Particularly, A. granulata is often found in rivers/lakes in the flood and delta

592 plains in eastern China and has been considered as an indicator of freshwater

593 discharge to estuaries (Chen et al., 2011; Dong et al., 2008; Liu et al., 2012; Wang et

594 al., 2009). We thus suppose high and constant percentages of A. granulata during

595 7100-6500 cal. yr BP in core DTX4 implied the strong freshwater influence of

596 Yangtze River runoff.

597 At some time after ca. 7000 cal. yr BP, although the marsh was dominated by $\mathrm{C}_{3}$

598 plants and strongly influenced by the Yangtze freshwater discharge, penetration of salt 
water occurred at core DTX4 as percentages of brackish benthic diatom and influence from marine POC/algae increased (Zone $\mathrm{II}_{2}$ and $\mathrm{II}_{3}$ in Fig. 5; Fig. 6). During this period, the infilling of the Palaeo-Taihu Estuary continued, but at a lower SR of 0.48

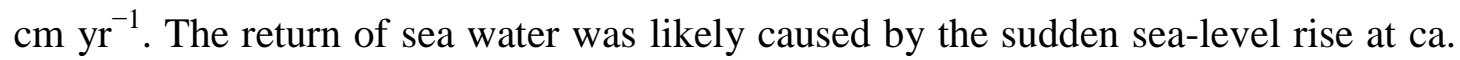
$6.8 \pm 0.2 \mathrm{ka} \mathrm{BP}$ due to the disappearance of the west section of the Laurentide ice sheet (Blanchon and Shaw, 1995; Carlson et al., 2007). From ca. 6500 to 5600 cal. yr $\mathrm{BP}$, sea water retreated slowly again and the sedimentary environment transitioned gradually from salt marsh to freshwater marsh in the area near core DTX4, reflected by the composition of organic matter over this period (Fig. 5), while site DTX10 was subaerially exposed (1.0-0.88 $\mathrm{m}$ in Fig. 7). Correspondingly, the infilling rate of the Palaeo-Taihu Estuary fell dramatically, likely signifying a process of shrinking due to the stable or slightly declining sea level from $~ 6300$ cal. yr BP (Fairbanks, 1989; Bard et al., 1996; Bird et al., 2007; Wang et al., accepted). After ca. 5600 cal. yr BP, the East Tiaoxi River Plain transitioned through a range of environments from stable freshwater marsh (core DTX4) or dry land (core DTX10), characterised by freshwater benthic diatoms and $\mathrm{C}_{3}$ terrestrial plants respectively (Fig. 3-7). In other words, no sea water penetration occurred and entirely freshwater environments persisted from ca. 5600 cal. yr BP throughout to the present. In terms of the Palaeo-Taihu Estuary, it likely shrank dramatically as it was filled up with sediment.

This study also demonstrates that viable and informative diatom counts can be made using the sodium polytungstate (SPT) density separation technique even on material which has very low diatom concentrations (here, largely as a result of dissolution). There is some indication that there is some preferential recovery of certain taxa (compare adjacent samples using the standard water-bath and SPT method in core DTX10 in Figure 4, for example for Diploneis smithii in Zone I) but there is clearly little systematic difference between the two methods, thus confirming 
625 the utility of the approach in such sediments. Results here support the use of SPT as a

626 very useful technique which may have wider application in estuarine and marine

627 sediments, where the option of working on material with well-preserved or abundant

628 diatoms (or other siliceous remains) may simply not be available, and yet may deliver

629 much information of great palaeoecological value, even with poorly preserved

630 assemblages (cf. Ryves et al. 2006, 2009).

\subsection{Environmental changes in the whole Taihu Plain}

632 We recognise six stages for the morphological and hydrologic evolution of the 633 Palaeo-Taihu Estuary according to the multi-proxy analyses in cores DTX4 and 634 DTX10. Before 7500 cal. yr BP, it was a high salinity estuary; 7500-7100 cal. yr BP, a 635 low salinity estuary influenced strongly by the Yangtze freshwater discharge; $6367100-7000$ cal. yr BP, it developed into a low salinity to freshwater marsh; 7000-6500 637 cal. yr BP, salt water penetrated into the marsh; 6500-5600 cal. yr BP, gradual retreat 638 of marine influence; and from 5600 cal. yr BP, stable freshwater conditions. A similar 639 history of hydrologic change can be inferred from the stratigraphic transections across 640 the Taihu Plain (Fig. 8). 

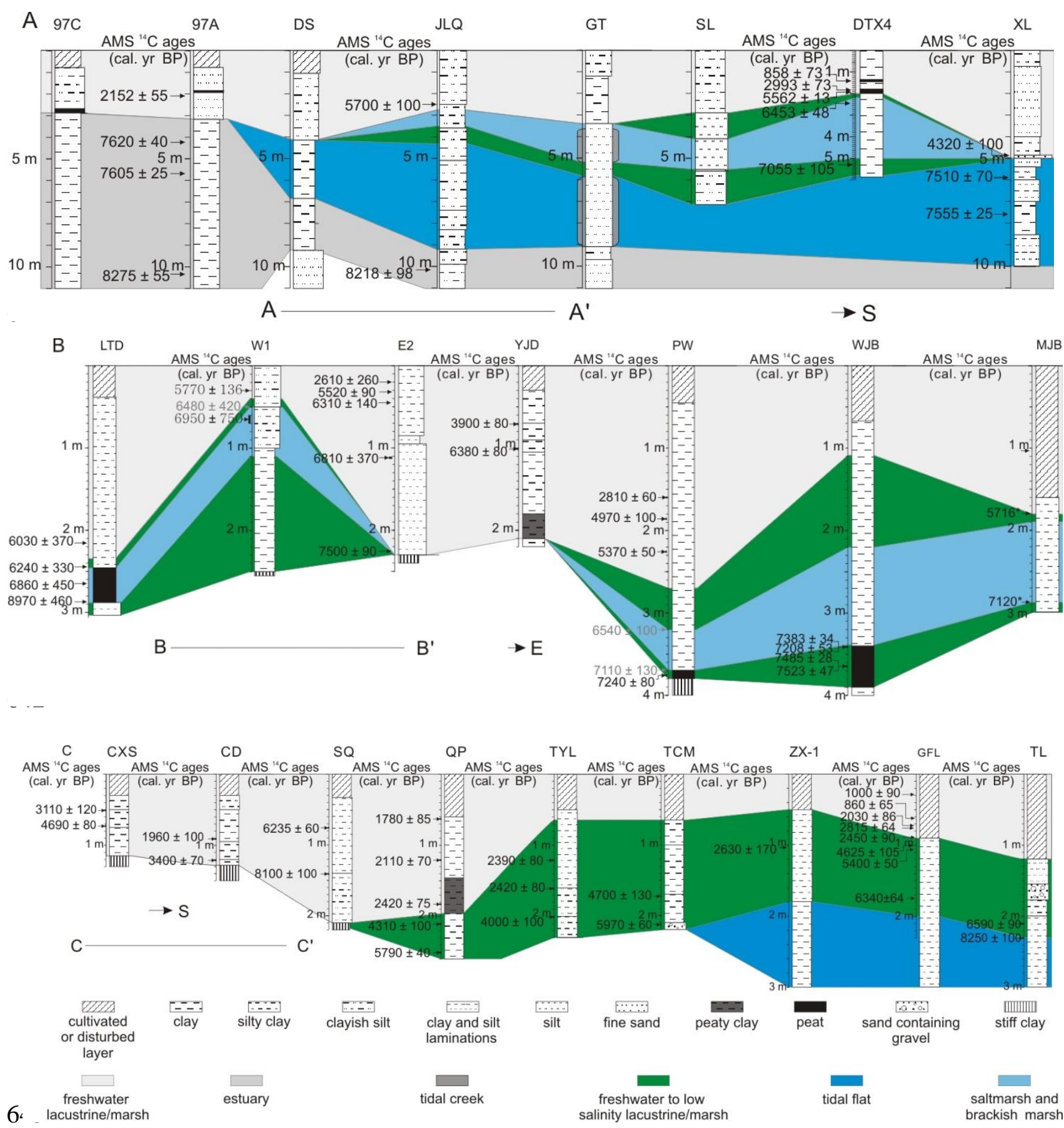

Fig. 8. Stratigraphic transections of collected cores, including section A-A' (A) and B-B' (B)

645 and C-C' (C). In section A-A', core 97C is after Ding (2004), core 97A after Zhou and Zheng (2000),

646 and core DS, JLQ, GT and SL are after Yan and Huang (1987) and Hong (1991), and core XL is after 

and Wang et al. (2001), core E2 after Wang et al. (2001), core YJD and PW after Zong et al. (2011,

649 2012b) and Innes et al. (2014), core WJB after Qin et al. (2011) and MJB after Long et al. (2014). In 650 section C-C', core CXS, CD and TYL are after Zong et al. (2012b), core SQ, TCM and TL after Zong 651 et al. (2011), core QP after Atahan et al. (2008) and Itzstein-Davey et al. (2007), ZX-1 after Chen et al. 652 (2005) and Tao et al. (2006) and core GEL after Wang et al. (2012). $0 \mathrm{~m}$ is the start depth for each core. 653 Ages in black are from references for each core and ages in grey black are linearly interpolated based 654 on "Clam" (Blaauw, 2010).

655 Estuarine facies dominated before 7500 cal. yr BP in multiple cores including 656 97C, 97A, DS, JLQ, GT and XL in the palaeo-Taihu Estuary (Fig. 8A; references for 657 these cores are in Supplementary Table 1), due to rapid sea-level rise in the early 658 Holocene (Wang et al., 2012). The sedimentary facies then turned into tidal flat in 659 these cores around $7500 \mathrm{cal}$. yr BP owing to the infilling of the estuary (Fig. 8A). 660 Brackish tidal flat conditions also occurred in other cores like ZX-1, GFL and TL in 661 the east Taihu Plain (Fig. 8C). As the relative sea level reached approximately $-6 \mathrm{~m}$ at 6627500 cal. yr BP (Wang et al., 2012), the late Pleistocene interfluve terrace T1 region 663 (including around Shanghai City) was a shallow sea environment due to this 664 transgressive phase (Li et al., 2001; Zong et al., 2004; Wang et al., 2012, 2013). No 665 sea water penetration occurred throughout the Holocene in the region of the late 666 Pleistocene interfluve terrace T3 (Fig. 1C) where palaeo-altitude was the highest 667 during the LGM (as recorded in core E2, YJD, CD, CXS and SQ; Fig. 8B and 8C). 668 The central Taihu Plain was isolated from western uplands due to sea water 669 inundation through the Palaeo-Taihu Estuary at ca. 7500 cal. yr BP (Fig. 9A). 

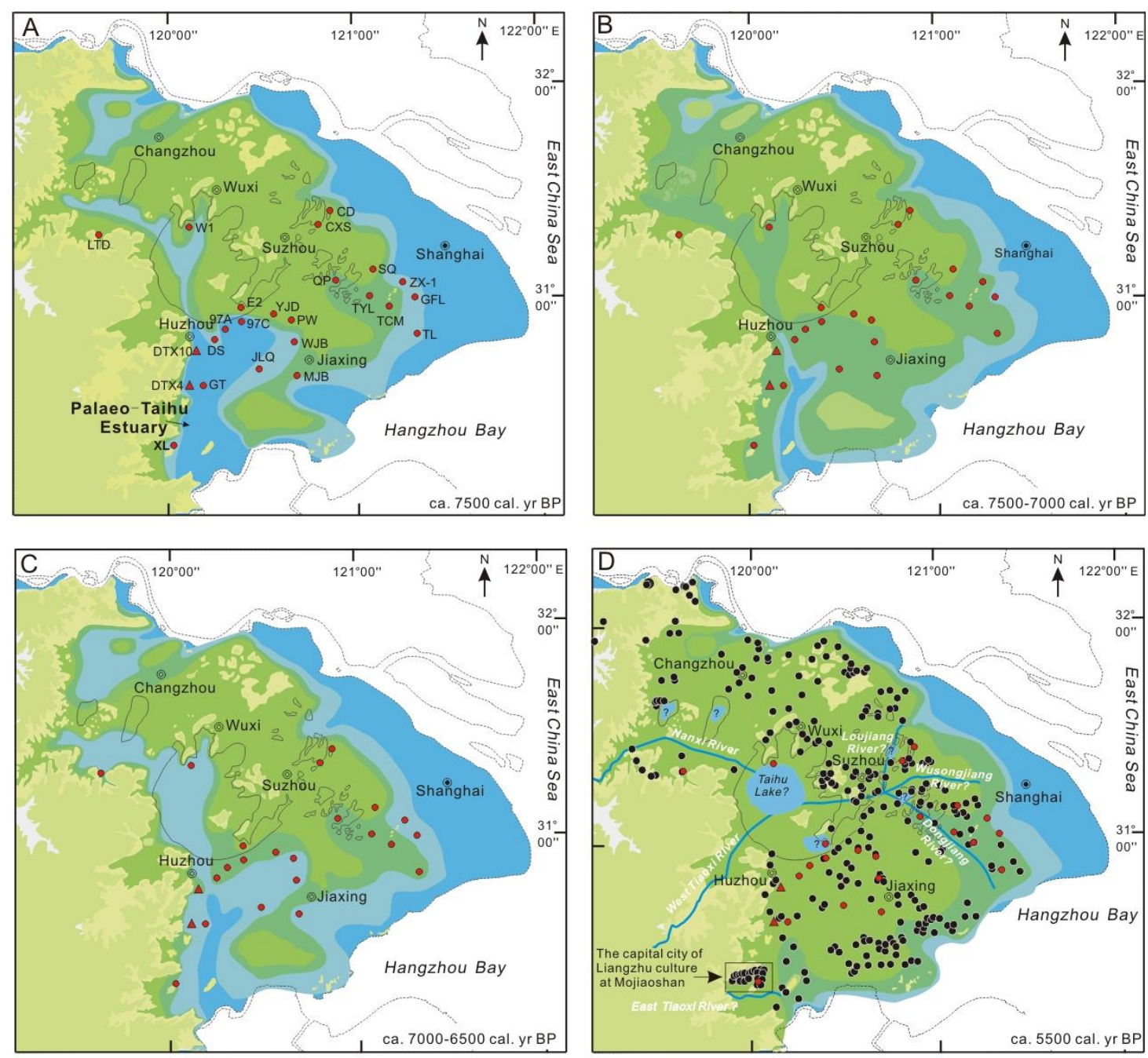

freshwater lacustrine or flooding plain

low salinity mars

tidal flat or brackish

estuary and shallow sea $520<$ elevation $(\mathrm{m}) \sim$ rivers and lakes

○ ० ० city - collected cores $\Delta$ core DTX4 and DTX10 • Liangzhu cultural sites

671 Fig. 9. Palaeogeographic map for the Taihu Plain before ca. 7500 cal. yr BP (A), during ca. 7500-7000

672 cal. yr BP (B), during ca. 7000-6500 cal. yr BP (C), and at ca. 5500 cal. yr BP (D). Rivers in (D) are

673 based on Hong (1991), and the possible formation of Taihu Lake is based on Wang et al. (2001). The

674 number of Liangzhu (5500-4500 cal. yr BP) cultural sites grew rapidly to 461, while it is only 78 and

67593 during the Majiabang (7000-5800 cal. yr BP) and Songze (5800-5500 cal. yr BP) period,

676 respectively (from Zheng, 2002; Chen, 2002; Xu, 2015). 
The marine regression at ca. 7500-7000 cal. yr BP recorded in core DTX4 and 679 DTX10 was also seen in cores in the Palaeo-Taihu Estuary (e.g. cores JLQ, GT and 680 WJB; Fig. 8A). In the central Taihu Plain, low salinity to freshwater marshes 681 developed at ca. 7600-7120 cal. yr BP in core WJB (Fig. 8B), indicated by reduced 682 concentration of marine dinoflagellate cysts and Chenopodiaceae pollen (Qin et al., 683 2011). Consequently, this sea water regression event promoted the rapid expansion of 684 low salinity to freshwater marshes, especially in the area of the Palaeo-Taihu valley 685 (Fig. 9B).

686 Evidence for sea water penetration after $7000 \mathrm{cal}$. yr BP was found in several 687 sediment cores (e.g. PW, WJB, MJB) in the central Taihu Plain (Fig. 8B) in addition 688 to those in the Palaeo-Taihu Estuary (Fig. 8A). Moreover, this marine transgression 689 reached areas where no sea water influence was observed in the records before. For 690 example, the foraminifera Ammonia compressiuscula and Ammonia cff. sobrina, 691 which prefer brackish tidal flat environments, occurred for the first time in the peat 692 layer dated at ca. 7000 cal. yr BP at site LTD, located at the head of the Palaeo-Taihu 693 valley, northwest of the Taihu Plain (Li et al., 2008; Fig. 8B). Marine and brackish 694 diatom species, marine species of dinoflagellate cysts and foraminifera were only 695 found at 50-90 cm (dated at ca. 7000 cal. yr BP) in core W1 in the north part of Taihu 696 Lake (Fig. 8B and 9C; Chang et al., 1994, Wang et al., 2001). Sea water also 697 inundated the low salinity marsh around core PW in the south east Taihu Plain at 698 some time after 7200 cal. yr BP (Fig. 8B; Zong et al., 2011; Innes et al., 2014). 699 Therefore, the transgression between ca. 7000-6500 cal. yr BP influenced a large area, 700 including the innermost Taihu Plain, through low-lying area such as the Palaeo-Taihu 701 valley (Fig. 9C). Low salinity marsh then returned from ca. 6200 to 5600 cal. yr BP at 702 sites LTD, W1, PW and DTX4 (Fig. 8), and thereafter stable freshwater conditions in 
703 the central Taihu Plain developed completely after ca. 5600 cal. yr BP, likely

704 indicating the closure of the Palaeo-Taihu Estuary (Fig. 9D).

705

706

707

708

709

710

711

712

713

714

715

716

717

718

719

720

721

722

723

724

725

726

727

\subsection{Role of hydrological environments on the development of rice farming}

Rice growth is susceptible to salinity conditions and demands suitable water depth, in addition to warm and humid climate (Zeng et al., 2003; Yu et al., 2000; Chen et al., 2005; Innes et al., 2009, 2014; Patalano et al., 2015). The Taihu Plain was semi-encircled by sea water before ca. 7500 cal. yr BP (Fig. 9A), corresponding with no sedentary Neolithic settlements and no remains of rice cultivation (Mo et al., 2011). Concurrent with withdrawal of sea water and expansion of low salinity and freshwater marshes between ca. 7500 cal. yr BP and ca. 7000 cal. yr BP, rice cultivation began (Cao et al., 2006; Fuller et al., 2007; Mo et al., 2011; Zong et al., 2011) and the Majiabang culture developed in the Taihu Plain, in addition to benefits of heat and precipitation provided by the optimum climate (Chen et al., 2005; Wang et al., 2005). However, no rapid advance in rice cultivation or productivity, or in the number of Neolithic sites, occurred during the late Majiabang and early Songze period. This is likely due to the lack of adequate freshwater supply, because the central Taihu plain was isolated from the western uplands by the Taihu-Palaeo Estuary until at around 5600 cal. yr BP (Fig. 9), and hence no river discharge from the western uplands entered the central Taihu plain.

We further suggest that the freshening of the East Tiaoxi River Plain or the shrinkage/closure of the Palaeo-Taihu Estuary at ca. 5600 cal. yr BP, was critical for the rapid expansion of rice agriculture across the whole Taihu Plain during the Liangzhu period (Fig. 9D), in the context of deteriorating climate conditions compared with the Majiabang and Songze period (Wang et al., 2005; Innes et al., 2014). Firstly, the shrinkage/closure of the Palaeo-Taihu Estuary, which is supported 
by extensive distribution of Liangzhu cultural sites in the Tiaoxi River Plain (Zheng, 2002), prevented the intrusion of sea water from Hangzhou Bay into the Taihu Plain,

730 allowing freshwater conditions, particularly in the southern and western parts. 731 Secondly, it restricted the discharge of freshwater from the western uplands (e.g. the 732 west Tiaoxi river) into the Hangzhou Bay, and instead, forced this freshwater to flow 733 eastwards, likely forming three previously existing rivers: the Loujiang River, the 734 Wusongjiang River and the Dongjiang River (Fig. 9D; Hong, 1991). This increasing 735 density of the river network would provide an increasing area of freshwater wetlands 736 available to be transformed into rice paddies and greater quantity of fresh water for 737 the east Taihu Plain. This conjecture is supported by the fact that the area of rice 738 paddy fields excavated in several archeological sites recently was several times larger 739 during the Liangzhu period than during the Majiabang and Songze period, and were 740 connected to natural and artificial creeks, instead of wells and ponds, which had 741 stronger capability of water storage (Cao et al., 2007; Hu et al., 2013; Zheng et al., 742 2014; Zhuang et al., 2014). Thirdly, new or enlarged freshwater marsh environments 743 of the East Tiaoxi River Plain would have supplied additional freshwater wetland 744 resources. Lastly, water level rise, in response to sea-level rise after the Taihu Plain 745 was separated from the Hangzhou Bay and the East China Sea, would also encourage 746 formation of freshwater wetlands (Hong, 1991; Chen et al., 1997). All these 747 advantages together would have increased opportunity for domesticated rice 748 cultivation in the whole Taihu Plain and rice productivity, supporting the continuous 749 and dramatic advancement of the Liangzhu culture.

750 We also speculate that the terrestrialisation and freshening of the East Tiaoxi 751 River Plain may have facilitated communication between the north and east Taihu 752 Plain, with the capital city of Liangzhu at Mojiaoshan, southwest of Taihu Plain (Fig. 753 9D) and even with areas south of Hangzhou Bay (Chen, 2015; Xu, 2015), given the 
754 barrier that the Palaeo-Taihu Estuary would have represented. Such easier 755 communication would support the development and flourishing of the Liangzhu 756 capital city. In return, the capital city would be act as a hub for advanced technology 757 and cultural innovation, promoting the further expansion of rice farming and cultural 758 development in the region over the Liangzhu period.

\section{Conclusions}

A multiproxy sedimentological analysis combining chronological, lithological, 762 geochemical and biological analyses of two sediment cores (DTX4 and DTX10) 763 collected from the East Tiaoxi River Plain, southern Yangtze delta Plain, have shed 764 light on changes in landscape and hydrology in this region over the last 7500 years. 765 Before ca. 7500 cal. yr BP, the Palaeo-Taihu Estuary existed along the present day 766 East Tiaoxi River Plain. It infilled rapidly by ca. 7500 cal. yr BP and was 767 characterised by low salinity conditions, because of the large supply of freshwater 768 from the Yangtze. Sea water, however, again penetrated the East Tiaoxi River Plain 769 after ca. 7000 cal. yr BP due to an abrupt sea-level rise, and a salt marsh environment 770 developed. This transgression was also recorded in other parts of the Taihu Plain 771 where no sea water influence occurred before, hence, it was possibly the largest 772 sea-level transgression during the Holocene, based on the synthesis of a large number 773 of hydrological and environmental records from the region. After ca. 6500 cal. yr BP, 774 sea-water penetration gradually declined and infilling rate of the Palaeo-Taihu Estuary 775 fell owing to slowing sea-level rise. The dramatic shrinkage/closure of the 776 Palaeo-Taihu Estuary occurred after ca. 5600 cal. yr BP, corresponding to the 777 formation of stable freshwater marsh (or subaerial land) conditions in the East Tiaoxi 778 River Plain. 
780 played an important role in the rise of rice cultivation and development of Neolithic 781 cultures across the Taihu Plain. Especially, the freshening of the East Tiaoxi River 782 Plain or its terrestrialisation after ca. 5600 cal. yr BP, was likely one critical 783 precondition encouraging rapid increase of rice productivity (and so cultural 784 development) during the Liangzhu period.

\section{Acknowledgments}

This study was supported by the National Natural Science Foundation of China 788 (Grant No. 41576042) and the China Scholarship Council Postgraduate Scholarship 789 Program, which allowed TC spending a year at Loughborough University. We are grateful to two anonymous reviewers for their helpful comments.

\section{References}

Atahan, P., Itzstein-Davey, F., Taylor, D., Dodson, J., Qin, J., Zheng, H., Brooks, 795 A., 2008. Holocene-aged sedimentary records of environmental changes and early 796 agriculture in the lower Yangtze, China. Quaternary Science Reviews 27, 556-570.

797 Bard, E., Hamelin, B., Arnold, M., Montaggioni, L., Cabioch, G., Faure, G., 798 Rougerie, F., 1996. Deglacial sea-level record from Tahiti corals and the timing of 799 global meltwater discharge. Nature 382, 241-244.

800 Battarbee, R.W., Jones, V.J., Flower, R.J., Cameron, N.G., Bennion, H., 801 Carvalho, L., Juggins, S., 2001. Diatoms, in: Smol, J.P., Birks, H.J.B., Last, W.M., 
803 Sediments: Terrestrial, Algal, and Siliceous Indicators. Springer Netherlands, 804 Dordrecht, pp. 155-202.

805

Bradley, R.S., Alverson, K. (Eds.), Tracking Environmental Change Using Lake

Battarbee, R.W., Kneen, M.J., 1982. The use of electronically counted microsphere sin absolute diatom analysis. Limnology \& Oceanography 27, 184-188.

Beuselinck, L., Govers, G., Poesen, J., Degraer, G., Froyen, L., 1998. Grain-size analysis by laser diffractometry: comparison with the sieve-pipette method. Catena 32, 193-208.

Bird, M., Fifield, L., Teh, T., Chang, C., Shirlaw, N., Lambeck, K., 2007. An inflection in the rate of early mid-Holocene eustatic sea-level rise: A new sea-level curve from Singapore. Estuarine, Coastal and Shelf Science 71, 523-536.

Blaauw, M., 2010. Methods and code for 'classical' age-modelling of radiocarbon sequences. Quaternary Geochronology 5, 512-518.

Blanchon, P., Shaw, J., 1995. Reef drowning during the last deglaciation: Evidence for catastrophic sea-level rise and ice-sheet collapse. Geology 23, 4-8.

Cao, Z.H., Ding, J.L., Hu, Z.Y., Knicker, H., Kögel-Knabner, I., Yang, L.Z., Yin, R., Lin, X.G., Dong, Y.H., 2006. Ancient paddy soils from the Neolithic age in China’s Yangtze River Delta. Naturwissenschaften 93, 232-236.

Cao, Z.H., Yang, L.Z., Lin, X.G., Hu, Z.Y., Dong, Y. H., Zhang, G.Y., Lu, Y.C., Yin, R., Wu, Y.L., Ding, J.L., Zheng, Y.F., 2007. Morphological characteristics of paddy fields, paddy soil profile, phytolith and fossil rice grain of the Neolithic age in Yangtze river delta. Acta Pedologica Sinica 44, 838-847 (In Chinese, with English abstract). 
826 Deglaciation of the Labrador Sector of the Laurentide Ice Sheet. Journal of Climate $827 \quad 20,5126-5133$.

828 Chang, W.Y.B., Xu, X.M., Yang, J.R., Liu, J.L., 1994. Evolution in Taihu Lake 829 ecosystem as evidence of changes in sediment profiles. Journal of Lake Science 6, $830 \quad 217-226$.

831 Chappell, J., Polach, H., 1991. Post-glacial sea-level rise from a coral record at 832 Huon Peninsula, Papua New Guinea. Nature 349, 147-149.

833 Chen, J., 2002. Neolithic cultures in the Yangtze delta, China and their 834 environments. PhD Thesis, East China Normal University, China (in Chinese, with 835 English abstract).

836 Chen, J., 2015. The Formation of the Songze Culture. Relics from South 1, 57-65 837 (in Chinese, with English abstract).

838 Chen, X., Yang, X., Dong, X., Liu, Q., 2011. Nutrient dynamics linked to 839 hydrological condition and anthropogenic nutrient loading in Chaohu Lake (southeast 840 China). Hydrobiologia 661, 223-234.

841 Chen, Z., Hong, X., Li, S., Wang, L., Shi, X., 1997. Study of archaeology-related 842 environment evolution of Taihu Lake in southern Chang Jiang Delta Plain. Acta 843 Geocgraphica Sinica 52, 131-137 (in Chinese, with English abstract).

844 Chen, Z., Wang, Z., Schneiderman, J., Taol, J., Cail, Y., 2005. Holocene climate 845 fluctuations in the Yangtze delta of eastern China and the Neolithic response. The 846 Holocene 15, 915-924. 
850 Ding, Y. F., 2004. Deposit record of climate and environmental changes of Taihu 851 Lake since 10,000 a. Master Thesis, East China Normal University, China (in Chinese, 852 with English abstract).

853 Dong, X., Bennion, H., Battarbee, R., Yang, X., Yang, H., Liu, E., 2008. 854 Tracking eutrophication in Taihu Lake using the diatom record: potential and 855 problems. Journal of Paleolimnology 40, 413-429.

856 Fairbanks, R.G., 1989. A 17, 000-year glacio-eustatic sea level record: influence 857 of glacial melting rates on the Younger Dryas event and deep-ocean circulation. 858 Nature 342, 637-642.

859 Fan, Y. P., 2011. On the development of rice farming in Tailake area during the 860 Neolithic age of China. Master Thesis, Nanjing Agriculture University, China (in 861 Chinese, with English abstract).

862 Fuller, D.Q., Harvey, E., LING, Q., 2007. Presumed domestication? Evidence 863 for wild rice cultivation and domestication in the fifth millennium BC of the Lower 864 Yangtze region. Antiquity 81, 316-331.

865 Gell, P., Tibby, J., Little, F., Baldwin, D., Hancock, G., 2007. The impact of 866 regulation and salinisation on floodplain lakes: The lower River Murray, Australia. 867 Hydrobiologia 591, 135-146.

868 Grönlund, T., 1993. Diatoms in surface sediments of the Gotland Basin in the 869 Baltic Sea. Hydrobiologia 269-270, 235-242. 
871 Marine Diatoms \& Dinoflagellates, 5-385. Quaternary Geology 11, 87-99 (in Chinese, with English abstract). Xing, B., 2013. Evidence for a Neolithic Age fire-irrigation paddy cultivation system in the lower Yangtze River Delta, China. Journal of Archaeological Science 40, $877 \quad 72-78$.

879 Environmental history, palaeoecology and human activity at the early Neolithic 880 forager/cultivator site at Kuahuqiao, Hangzhou, eastern China. Quaternary Science 881 Reviews 28, 2277-2294.

887 Environmental and cultural changes during the terminal Neolithic: Qingpu, Yangtze delta, eastern China. The Holocene 17, 875-887.

889 Jiang, L., Liu, L., 2006. New evidence for the origins of sedentism and rice 890 domestication in the Lower Yangzi River, China. Antiquity 80, 355-361.

891 Juggins, S., 1991-2009. C2 Data Analysis. Newcastle University, Newcastle. 892 Available at: http://www.staff.ncl.ac.uk/staff/stephen.juggins/software/C2Home.htm. 
Juggins, S., 2013. Quantitative reconstructions in palaeolimnology: new 894 paradigm or sick science? Quaternary Science Reviews 64, 20-32. Kilham, P., 1990. Ecology of Melosira Species in the Great Lakes of Africa, in: 896 Tilzer, M.M., Serruya, C. (Eds.), Large Lakes: Ecological Structure and Function. 897 Springer Berlin Heidelberg, Berlin, Heidelberg, pp. 414-427. 901 York.

Krammer, K., Lange-Bertalot, H., 1988. Bacillariophyceae. 2: Teil: 903 Bacillariaceae, Epithemiaceae, Surirellaceae. In: Ettl, H., Gärtner, G., Gerloff, J., 904 Heynig, H., Mollenhauer, D. (Eds.), Süsswasserflora von Mitteleuropa, Band 2/2. 905 Gustav Fischer Verlag, Stuttgart, New York.

906 Krammer, K., Lange-Bertalot, H., 1991a. Bacillariophyceae. 3: Teil: Centrales, 907 Fragilariaceae, Eunotiaceae. In: Ettl, H., Gärtner, G., Gerloff, J., Heynig, H., 908 Mollenhauer, D. (Eds.), Süsswasserflora von Mitteleuropa, Band 2/3. Gustav Fischer 909 Verlag, Stuttgart, Jena.

910 Krammer, K., Lange-Bertalot, H., 1991b. Bacillariophyceae. 4: Teil: 911 achnanthaceae. In: Ettl, H., Gärtner, G., Gerloff, J., Heynig, H., Mollenhauer, D. 912 (Eds.), Süsswasserflora von Mitteleuropa, Band 2/4. Gustav Fischer Verlag, Stuttgart, 913 Jena.

914 Lamb, A.L., Vane, C.H., Wilson, G.P., Rees, J.G., Moss-Hayes, V.L., 2007. 915 Assessing $\delta^{13} \mathrm{C}$ and $\mathrm{C} / \mathrm{N}$ ratios from organic material in archived cores as Holocene 
916 sea level and palaeoenvironmental indicators in the Humber Estuary, UK. Marine 917 geology 244, 109-128.

918 Lawler, A., 2009. Beyond the Yellow River: How China Became China. Science $919325,930-935$.

920 Leng, M.J., Lewis, J.P., 2017. C/N ratios and Carbon Isotope Composition of 921 Organic Matter in Estuarine Environments, in: Weckström, K., Saunders, K.M., Gell, 922 P.A., Skilbeck, C.G. (Eds.), Applications of Paleoenvironmental Techniques in 923 Estuarine Studies. Springer Netherlands, Dordrecht, pp. 213-237.

924 Li, C.X., Chen, Q.Q., Zhang, J.Q., Yang, S., Fan, D., 2000. Stratigraphy and 925 paleoenvironmental changes in the Yangtze Delta during the Late Quaternary. Journal 926 of Asian Earth Sciences 18, 453-469.

927 Li, C.X., Wang, P.X., Sun, H.P., Zhang, J.Q., Fan, D., Deng, B., 2002. Late 928 Quaternary incised-valley fill of the Yangtze delta (China): its stratigraphic 929 framework and evolution. Sedimentary Geology 152, 133-158.

930 Li, L., Zhu, C., Lin, L., Zhao, Q., Shi, G., Zhu, H., 2008. Transgression records 931 between $7500-5400 \mathrm{BC}$ on the stratum of the Luotuodun site in Yixing, Jiangsu 932 province. Acta Geographica Sinica 63, 1189-1197.

933 Liu, L., Chen, X., 2012. The archaeology of China: From the late paleolithic to 934 the early bronze age. Cambridge World Archaeology, Cambridge.

935 Liu, Q., Yang, X., Anderson, N.J., Liu, E., Dong, X., 2012. Diatom ecological 936 response to altered hydrological forcing of a shallow lake on the Yangtze floodplain, 937 SE China. Ecohydrology 5, 316-325. 
Liu, Y., Sun, Q., Thomas, I., Zhang, L., Finlayson, B., Zhang, W., Chen, J., Chen,

939 Z., 2015. Middle Holocene coastal environment and the rise of the Liangzhu City

940 complex on the Yangtze delta, China. Quaternary Research 84, 326-334.

941 Long, T., Qin, J., Atahan, P., Mooney, S., Taylor, D., 2014. Rising waters: New 942 geoarchaeological evidence of inundation and early agriculture from former 943 settlement sites on the southern Yangtze Delta, China. Holocene 24, 546-558.

944 Meyers, P.A., 2003. Applications of organic geochemistry to paleolimnological 945 reconstructions: a summary of examples from the Laurentian Great Lakes. Organic 946 Geochemistry 34, 261-289.

947 Middelburg, J.J., Nieuwenhuize, J., 1998. Carbon and nitrogen stable isotopes in 948 suspended matter and sediments from the Schelde Estuary. Marine chemistry 60, $949 \quad 217-225$.

950 Mo, D., Zhao, Z., Xu, J., Li, M., 2011. Holocene Environmental Changes and the 951 Evolution of the Neolithic Cultures in China, in: Martini, P.I., Chesworth, W. (Eds.), 952 Landscapes and Societies: Selected Cases. Springer Netherlands, Dordrecht, pp, $953 \quad 299-319$.

954 Müller, A., Mathesius, U., 1999. The palaeoenvironments of coastal lagoons in 955 the southern Baltic Sea, I. The application of sedimentary $\mathrm{C}_{\text {org }} / \mathrm{N}$ ratios as source 956 indicators of organic matter. Palaeogeography, Palaeoclimatology, Palaeoecology 145, $957 \quad 1-16$.

958 Müller, A., Voss, M., 1999. The palaeoenvironments of coastal lagoons in the 959 southern Baltic Sea, II. $\delta^{13} \mathrm{C}$ and $\delta^{15} \mathrm{~N}$ ratios of organic matter-sources and sediments. 960 Palaeogeography, Palaeoclimatology, Palaeoecology 145, 17-32. 
Owen, R.B., Crossley, R., 1992. Spatial and temporal distribution of diatoms in

962 sediments of Lake Malawi, Central Africa, and ecological implications. Journal of 963 Paleolimnology 7, 55-71.

964 Patalano, R., Wang, Z., Leng, Q., Liu, W., Zheng, Y., Sun, G., Yang, H., 2015. 965 Hydrological changes facilitated early rice farming in the lower Yangtze River Valley 966 in China: A molecular isotope analysis. Geology 43.

967 Qin, J., Taylor, D., Atahan, P., Zhang, X., Wu, G., Dodson, J., Zheng, H., 968 Itzstein-Davey, F., 2011. Neolithic agriculture, freshwater resources and rapid 969 environmental changes on the lower Yangtze, China. Quaternary Research 75, 55-65.

970 Reimer, P.J., Baillie, M.G.L., Bard, E., Bayliss, A., Beck, J.W., Blackwell, P.G., 971 Ramsey, C.B., Buck, C.E., Burr, G.S., Edwards, R.L., 2009. IntCal09 and Marine09 972 Radiocarbon Age Calibration Curves, 0-50,000 Years cal. BP. Radiocarbon 51, 973 1111-1150.

974 Renberg, I., 1990. A procedure for preparing large sets of diatom slides from 975 sediment cores. Journal of Paleolimnology 4, 87-90.

976 Ryu, E., Yi, S., Lee, S.-J., 2005. Late Pleistocene-Holocene paleoenvironmental 977 changes inferred from the diatom record of the Ulleung Basin, East Sea (Sea of Japan). 978 Marine Micropaleontology 55, 157-182.

979 Ryves, D.B., Juggins, S., Fritz, S.C., Battarbee, R.W., 2001. Experimental 980 diatom dissolution and the quantification of microfossil preservation in sediments. 981 Palaeogeography Palaeoclimatology Palaeoecology 172, 99-113.

982 Ryves, D.B., Clarke, A.L., Appleby, P.G., Amsinck, S.L., Jeppesen, E., 983 Landkildehus, F., Anderson, N.J., 2004. Reconstructing the salinity and environment 
984 of the Limfjord and Vejler. Canadian Journal of Fisheries \& Aquatic Sciences 61, 985 1988-2006 (1919).

986 Ryves, D.B., Battarbee, R.W., Juggins, S., Fritz, S.C., Anderson, N.J., 2006. 987 Physical and chemical predictors of diatom dissolution in freshwater and saline lake 988 sediments in North America and West Greenland. Limnology and Oceanography 51, $989 \quad 1355-1368$.

990 Ryves, D.B., Battarbee, R.W., Fritz, S.C., 2009. The dilemma of disappearing 991 diatoms: Incorporating diatom dissolution data into palaeoenvironmental modelling 992 and reconstruction. Quaternary Science Reviews 28, 120-136.

993 Song, B., Li, Z., Saito, Y., Okuno, J.I., Li, Z., Lu, A., Hua, D., Li, J., Li, Y., 994 Nakashima, R., 2013. Initiation of the Changjiang (Yangtze) delta and its response to 995 the mid-Holocene sea level change. Palaeogeography Palaeoclimatology 996 Palaeoecology 388, 81-97.

997 Stabell, B., 1985. The development and succession of taxa within the diatom 998 genus Fragilaria Lyngbye as a response to basin isolation from the sea. Boreas 14, $999 \quad 273-286$.

1000 Stanley, D.J., 2000. Radiocarbon Dates in China's Holocene Yangtze Delta: 1001 Record of Sediment Storage and Reworking, Not Timing of Deposition. Journal of 1002 Coastal Research 16, 1126-1132.

1003 Tada, R., Irino, T., Koizumi, I., 1999. Land-ocean linkages over orbital and 1004 millennial timescales recorded in Late Quaternary sediments of the Japan Sea. 1005 Paleoceanography 14, 236-247. 
Talma, A.S., Vogel, J.C., 1993. A Simplified Approach to Calibrating C14 Dates.

1007 Radiocarbon 35 317-322.

1008

1009

1010

1011

1012

1013

1014

1015

1016

1017

1018

1019

1020

1021

1022

1023

1024

1025

1026

1027

Tao, J., Chen, M.T., Xu, S., 2006. A Holocene environmental record from the southern Yangtze River delta, eastern China. Palaeogeography, Palaeoclimatology, Palaeoecology 230, 204-229.

Thornton, S.F., McManus, J., 1994. Application of Organic Carbon and Nitrogen Stable Isotope and C/N Ratios as Source Indicators of Organic Matter Provenance in Estuarine Systems: Evidence from the Tay Estuary, Scotland. Estuarine Coastal \& Shelf Science 38, 219-233.

van der Werff, A., Huls, H., 1957-1974, Reprinted 1976. Diatomeënflora van Nederland. Koeltz Science Publishers, Koenigstein.

Vo $\beta$, M., Struck, U., 1997. Stable nitrogen and carbon isotopes as indicator of eutrophication of the Oder river (Baltic sea). Marine chemistry 59, 35-49.

Vos, P.C., de Wolf, H., 1993. Diatoms as a tool for reconstructing sedimentary environments in coastal wetlands; methodological aspects. Hydrobiologia 269, 285-296.

Wang, C., Li, X., Lai, Z., Tan, X., Pang, S., Yang, W., 2009. Seasonal variations of Aulacoseira granulata population abundance in the Pearl River Estuary. Estuarine Coastal \& Shelf Science 85, 585-592.

Wang, J., Chen, X., Zhu, X.H., Liu, J.L., Chang, W.Y.B., 2001. Taihu Lake, lower Yangtze drainage basin: evolution, sedimentation rate and the sea level. Geomorphology 41, 183-193. 
1029 M.J., Dykoski, C.A., Li, X., 2005. The Holocene Asian monsoon: links to solar 1030 changes and North Atlantic climate. Science 308, 854-857.

1031 Wang, Z., Zhuang, C., Saito, Y., Chen, J., Zhan, Q., Wang, X., 2012. Early 1032 mid-Holocene sea-level change and coastal environmental response on the southern 1033 Yangtze delta plain, China: implications for the rise of Neolithic culture. Quaternary 1034 Science Reviews 35, 51-62.

1035 Wang, Z., Zhan, Q., Long, H., Saito, Y., Gao, X., Wu, X., Li, L., Zhao, Y., 2013. 1036 Early to mid-Holocene rapid sea-level rise and coastal response on the southern 1037 Yangtze delta plain, China. Journal of Quaternary Science 28, 659-672.

1038 Wang, Z., Ryves, D.V., Lei, S., Nian, X., Lv, Y., Tang, L., Wang, L., Wang, J., 1039 Chen, J., (accepted). Middle Holocene marine flooding and human response in the 1040 south Yangtze coastal plain, East China. Quaternary Science reviews.

1041 Wilson, G.P., Lamb, A.L., Leng, M.J., Gonzalez, S., Huddart, D., 2005. $\delta^{13}$ C and $1042 \mathrm{C} / \mathrm{N}$ as potential coastal palaeoenvironmental indicators in the Mersey Estuary, UK. 1043 Quaternary Science Reviews 24, 2015-2029.

1044 Witkowski, A., Dr, Ichtiologii, Lange-Bertalot, H., Metzeltin, D., 2000. Diatom 1045 flora of marine coasts I. A.R.G. Gantner Verlag K.G.

$1046 \mathrm{Xu}, \mathrm{P} ., 2$ 2015. Research on the archaeological cultures of Neolithic age in 1047 Ningzhen area and Huantaihu area. PhD Thesis, Jilin University, China (in Chinese, 1048 with English abstract). 
1050 the Hangzhou-Jiaxing-Huzhou Plain. Acta Geographica Sinica 42, 1-15 (in Chinese, 1051 with English abstract).

1052 Yang, S., Tang, M., Yim, W.W.S., Zong, Y., Huang, G., Switzer, A.D., Saito, Y., 1053 2011. Burial of organic carbon in Holocene sediments of the Zhujiang (Pearl River) 1054 and Changjiang (Yangtze River) estuaries. Marine chemistry 123, 1-10.

1055 Yu, S., Zhu, C., Song, J., Qu, W., 2000. Role of climate in the rise and fall of 1056 Neolithic cultures on the Yangtze Delta. Boreas 29, 157-165.

1057 Zeng, L., Lesch, S.M., Grieve, C.M., 2003. Rice growth and yield respond to 1058 changes in water depth and salinity stress. Agricultural Water Management 59, 67-75.

1059 Zhan, Q., Wang, Z.H., Xie, Y., Xie, J., He, Z., 2012. Assessing C/N and $\delta^{13} \mathrm{C}$ as 1060 indicators of Holocene sea level and freshwater discharge changes in the subaqueous 1061 Yangtze delta, China. The Holocene 22, 697-704.

1062 Zhang, J., Wu, Y., Jennerjahn, T.C., Ittekkot, V., He, Q., 2007. Distribution of 1063 organic matter in the Changjiang (Yangtze River) Estuary and their stable carbon and 1064 nitrogen isotopic ratios: Implications for source discrimination and sedimentary 1065 dynamics. Marine chemistry 106, 111-126.

1066 Zhang, X., Huang, D., Deng, H., Snape, C., Meredith, W., Zhao, Y., Du, Y., 1067 Chen, X., Sun, Y., 2015. Radiocarbon dating of charcoal from the Bianjiashan site in 1068 Hangzhou: New evidence for the lower age limit of the Liangzhu Culture. Quaternary 1069 Geochronology 30, Part A, 9-17. 
Zheng, C.G., 2002. Environmental archaeology on the Temporal-Spatial

1071 distribution of Cultures sites in Taihu Lake area during 7 ka BP - 4 ka BP. PhD Thesis,

1072 Nanjing University, China (in Chinese, with English abstract).

1073 Zheng, Y. F., Chen, X.G., Ding, P., 2014. Studies on the archaeological paddy

1074 fields at Maoshan site in Zhejiang. Quaternary Sciences, 34, 85-96.

1075 Zheng, Y., Sun, G., Chen, X., 2012. Response of rice cultivation to fluctuating 1076 sea level during the Mid-Holocene. Chinese Science Bulletin 57, 370-378.

1077 Zhou, H., Zheng, X., 2000. The Impact of Environmental Changes on the

1078 Development of Prehistoric Civilization: The Decline of the Ancient Liang zhu

1079 Culture in the Southern Plain of Yangtze River Delta. Journal of East China Normal

1080 University (Natural Science) 4, 71-77 (in Chinese, with English abstract).

1081 Zhu, N., 2006. Impacts of the rice farming on cultural development in the Taihu 1082 and Hangzhou Bay area, In: Shanghai Museum (Eds.), Symposium on the civilization 1083 course of the lower reach region of the Yangzte Rvier. Shanghai Book/paint publishers, 1084 Shanghai, pp, 69-88 (in Chinese).

1085 Zhuang, Y., Ding, P., French, C., 2014. Water management and agricultural 1086 intensification of rice farming at the late-Neolithic site of Maoshan, Lower Yangtze 1087 River, China. Holocene 24, 531-545.

1088 Zong, Y.Q., 2004. Mid-Holocene sea-level highstand along the southeast coast 1089 of China. Quaternary International 117, 55-67.

1090 Zong, Y., Chen, Z., Innes, J.B., Chen, C., Wang, Z., Wang, H., 2007. Fire and 1091 flood management of coastal swamp enabled first rice paddy cultivation in east China. 1092 Nature 449, 459-462. 
1094 hydrology and salinity changes in the east Taihu area of the lower Yangtze wetlands, 1095 China. Quaternary Research 76, 69-82.

1096 Zong, Y., Wang, Z., Innes, J., Chen, Z., 2012a. Holocene environmental change 1097 and Neolithic rice agriculture in the lower Yangtze region of China: A review. 1098 Holocene 22, 623-635.

1099 Zong, Y., Innes, J.B., Wang, Z., Chen, Z., 2012b. Environmental change and 1100 Neolithic settlement movement in the lower Yangtze wetlands of China. Holocene 22, $1101 \quad 659-673$.

1102 Zuo, X., Lu, H., Jiang, L., Zhang, J., Yang, X., Huan, X., He, K., Wang, C., Wu, 1103 N., 2017. Dating rice remains through phytolith carbon-14 study reveals 1104 domestication at the beginning of the Holocene. Proceedings of the National 1105 Academy of Sciences of the United States of America 114, 6486. 


\section{Supplementary Table 1}

3 Dating results for collected cores from previous studies

\begin{tabular}{|c|c|c|c|c|c|c|}
\hline $\begin{array}{l}\text { Core } \\
\text { name }\end{array}$ & Location & Depth (m) & $\begin{array}{c}\text { Dating } \\
\text { material }\end{array}$ & $\begin{array}{c}\text { Conventional } \\
\text { age (yr BP) }\end{array}$ & $\begin{array}{c}\text { Calibrated } \\
\text { age }(2 \delta, \text { cal. } \\
\text { yr BP })\end{array}$ & Reference \\
\hline \multirow[t]{5}{*}{ 97A } & I & 2.1 & Peat & I & $\begin{array}{c}2305-2000(1 \\
\delta)\end{array}$ & $\begin{array}{l}\text { Zhou and } \\
\text { Zheng, } 2000\end{array}$ \\
\hline & & 4.11 & $\begin{array}{c}\text { Plant } \\
\text { fragment }\end{array}$ & I & $\begin{array}{c}7660-75809(1 \\
\delta)\end{array}$ & \\
\hline & & 5.78 & $\begin{array}{c}\text { Plant } \\
\text { fragment }\end{array}$ & I & $\begin{array}{c}7630-7580(1 \\
\delta)\end{array}$ & \\
\hline & & 10.2 & Shell & I & $\begin{array}{c}8330-8220(1 \\
\delta)\end{array}$ & \\
\hline & & 13.8 & $\begin{array}{c}\text { Plant } \\
\text { fragment }\end{array}$ & I & $\begin{array}{c}8425-8365(1 \\
\delta)\end{array}$ & \\
\hline \multirow[t]{2}{*}{ JLQ } & I & 2.5 & $\begin{array}{c}\text { Bulk } \\
\text { organic }\end{array}$ & $4975 \pm 70$ & $5597-5797$ & $\begin{array}{l}\text { Hong, 1991; } \\
\text { Zong et al., } \\
\quad 2011\end{array}$ \\
\hline & & 11.2 & $\begin{array}{l}\text { Bulk } \\
\text { organic }\end{array}$ & $7400 \pm 80$ & $8039-8372$ & \\
\hline $\begin{array}{c}\text { DS, } \\
\text { SL, GT }\end{array}$ & I & I & I & I & I & $\begin{array}{c}\text { Hong, 1991; } \\
\text { Yan and } \\
\text { Huang, 1987 }\end{array}$ \\
\hline \multirow[t]{3}{*}{ XL } & $\begin{array}{l}30^{\circ} 24^{\prime} 05^{\prime \prime} \mathrm{N} \\
120^{\circ} 01^{\prime} 38^{\prime \prime} \mathrm{E}\end{array}$ & 4.87 & Wood & $3940 \pm 40$ & $4420-4220$ & $\begin{array}{l}\text { Liu et al., } \\
2015\end{array}$ \\
\hline & & 5.9 & Seed & $5700 \pm 40$ & $7580-7440$ & \\
\hline & & 7.6 & $\begin{array}{c}\text { Plant } \\
\text { material }\end{array}$ & $6420 \pm 40$ & $7560-7530$ & \\
\hline \multirow[t]{4}{*}{ LTD } & $\begin{array}{c}31^{\circ} 21^{\prime} \mathrm{N} \\
12119^{\circ} 42^{\prime} \mathrm{E}\end{array}$ & 2.16 & Mud & $5281 \pm 175$ & $6400-5660$ & $\begin{array}{l}\text { Li et al., } \\
2008\end{array}$ \\
\hline & & 2.45 & Peat & $5464 \pm 165$ & $6570-5910$ & \\
\hline & & 2.64 & Peat & $6016 \pm 200$ & $7310-6410$ & \\
\hline & & 2.88 & Peat & $8036 \pm 190$ & $9430-8510$ & \\
\hline \multirow[t]{2}{*}{ W1 } & I & 0.3 & Pollen & $5020 \pm 75$ & $5638-5910$ & $\begin{array}{l}\text { Chang et al., } \\
\text { 1994; Wang } \\
\text { et al., } 2001\end{array}$ \\
\hline & & $0.60-0.70$ & Mud & $6145 \pm 370$ & $6206-7703$ & \\
\hline
\end{tabular}




\begin{tabular}{|c|c|c|c|c|c|c|}
\hline & & $1.60-1.70$ & Mud & $8575 \pm 410$ & $8544-10593$ & \\
\hline \multirow[t]{5}{*}{ E2 } & I & 0.2 & Mud & $2575 \pm 110$ & $2354-2868$ & $\begin{array}{l}\text { Chang et al., } \\
\text { 1994; Wang } \\
\text { et al., } 2001\end{array}$ \\
\hline & & 0.32 & Mud & $4765 \pm 70$ & $5433-5607$ & \\
\hline & & 0.45 & Mud & $5495 \pm 75$ & 6175-6448 & \\
\hline & & $1.14-1.25$ & Mud & $5970 \pm 170$ & $6441-7184$ & \\
\hline & & 2.26 & Mud & $6575 \pm 75$ & $7410-7585$ & \\
\hline \multirow[t]{2}{*}{ YJD } & $\begin{array}{l}30^{\circ} 59^{\prime} 45^{\prime \prime} \mathrm{N} \\
120^{\circ} 35^{\prime} 31^{\prime \prime} \mathrm{E}\end{array}$ & $0.7-0.72$ & $\begin{array}{l}\text { Pollen } \\
\text { residue }\end{array}$ & $3570 \pm 40$ & $3816-3977$ & $\begin{array}{l}\text { Zong et al., } \\
2012 \mathrm{~b}\end{array}$ \\
\hline & & $1.0-1.02$ & $\begin{array}{l}\text { Pollen } \\
\text { residue }\end{array}$ & $5600 \pm 40$ & $6299-6453$ & \\
\hline \multirow[t]{4}{*}{ PW } & $\begin{array}{l}30^{\circ} 57^{\prime} 30^{\prime \prime} \mathrm{N} \\
120^{\circ} 38^{\prime} 25^{\prime \prime} \mathrm{E}\end{array}$ & $1.59-1.61$ & $\begin{array}{l}\text { Pollen } \\
\text { residue }\end{array}$ & $2700 \pm 40$ & $2750-2868$ & $\begin{array}{l}\text { Innes et al., } \\
2014\end{array}$ \\
\hline & & $1.85-1.87$ & $\begin{array}{l}\text { Pollen } \\
\text { residue }\end{array}$ & $4430 \pm 40$ & $4871-5075$ & \\
\hline & & $2.25-2.27$ & $\begin{array}{l}\text { Pollen } \\
\text { residue }\end{array}$ & $4720 \pm 40$ & $5323-5417$ & \\
\hline & & $3.75-3.77$ & Peat & $6290 \pm 50$ & $7153-7320$ & \\
\hline \multirow[t]{5}{*}{ WJB } & $\begin{array}{l}30^{\circ} 49^{\prime} 04^{\prime \prime} \mathrm{N} \\
120^{\circ} 36^{\prime} 56^{\prime \prime} \mathrm{E}\end{array}$ & $3.5-3.52$ & Charcoal & $6410 \pm 60$ & $7245-7434$ & $\begin{array}{l}\text { Qin et al., } \\
2011\end{array}$ \\
\hline & & $3.5-3.52$ & $\begin{array}{l}\text { Pollen } \\
\text { residue }\end{array}$ & $6250 \pm 70$ & $6970-7315$ & \\
\hline & & $3.74-3.76$ & Peat & $6600 \pm 50$ & $7431-7569$ & \\
\hline & & $3.74-3.76$ & Peat & $6630 \pm 60$ & $7429-7590$ & \\
\hline & & $6-6.02$ & Clay & $7350 \pm 60$ & 8024-8318 & \\
\hline
\end{tabular}




\begin{tabular}{|c|c|c|c|c|c|c|}
\hline \multirow[t]{3}{*}{$\overline{Z X-1}$} & 1 & 1.1 & $\begin{array}{l}\text { Organic- } \\
\text { rich mud }\end{array}$ & $2580 \pm 60$ & $2462-2794$ & \multirow[t]{3}{*}{$\begin{array}{c}\text { Chen et al., } \\
\text { 2005; Tao et } \\
\text { al., } 2006\end{array}$} \\
\hline & & 4.5 & Shell & $4160 \pm 40$ & $3875-4221$ & \\
\hline & & 8.8 & $\begin{array}{l}\text { Organic- } \\
\text { rich mud }\end{array}$ & $6850 \pm 80$ & $7570-7853$ & \\
\hline \multirow[t]{2}{*}{ CXS } & $\begin{array}{l}31^{\circ} 22^{\prime} 44^{\prime \prime} \mathrm{N} \\
120^{\circ} 47^{\prime} 30^{\prime \prime} \mathrm{E}\end{array}$ & $0.5-0.52$ & $\begin{array}{l}\text { Pollen } \\
\text { residue }\end{array}$ & $2960 \pm 40$ & $2985-3234$ & $\begin{array}{l}\text { Zong et al., } \\
\text { 2012b }\end{array}$ \\
\hline & & $0.72-0.74$ & $\begin{array}{l}\text { Pollen } \\
\text { residue }\end{array}$ & $4190 \pm 40$ & $4609-4768$ & \\
\hline \multirow[t]{2}{*}{ CD } & $\begin{array}{l}31^{\circ} 24^{\prime} 16^{\prime \prime} \mathrm{N} \\
120^{\circ} 50^{\prime} 37^{\prime \prime} \mathrm{E}\end{array}$ & $0.9-0.92$ & $\begin{array}{l}\text { Pollen } \\
\text { residue }\end{array}$ & $2000 \pm 40$ & $1867-2060$ & $\begin{array}{l}\text { Zong et al., } \\
2012 \mathrm{~b}\end{array}$ \\
\hline & & $1.2-1.22$ & $\begin{array}{c}\text { Plant } \\
\text { fragment }\end{array}$ & $3160 \pm 40$ & 3324-3459 & \\
\hline \multirow[t]{2}{*}{ SQ } & $\begin{array}{l}31^{\circ} 11^{\prime} 50^{\prime \prime} \mathrm{N} \\
121^{\circ} 066^{\prime} 25^{\prime \prime} \mathrm{E}\end{array}$ & $0.75-0.77$ & $\begin{array}{l}\text { Pollen } \\
\text { residue }\end{array}$ & $5410 \pm 40$ & $6175-6296$ & $\begin{array}{l}\text { Zong et al., } \\
2011\end{array}$ \\
\hline & & $1.40-1.42$ & $\begin{array}{l}\text { Pollen } \\
\text { residue }\end{array}$ & $7310 \pm 50$ & $8005-8204$ & \\
\hline \multirow[t]{8}{*}{$\mathbf{Q P}$} & $\begin{array}{l}31^{\circ} 07^{\prime} 44^{\prime \prime} \mathrm{N} \\
120^{\circ} 54^{\prime} 39^{\prime \prime} \mathrm{E}\end{array}$ & $0.62-0.64$ & $\begin{array}{l}\text { Pollen } \\
\text { residue }\end{array}$ & $1827 \pm 35$ & $1695-1865$ & $\begin{array}{c}\text { Atahan et } \\
\text { al., 2008; } \\
\text { Itzstein- } \\
\text { Davey et al., } \\
2007\end{array}$ \\
\hline & & $1.20-1.22$ & $\begin{array}{l}\text { Pollen } \\
\text { residue }\end{array}$ & $2152 \pm 35$ & $2038-2185$ & \\
\hline & & $1.82-1.84$ & $\begin{array}{l}\text { Pollen } \\
\text { residue }\end{array}$ & $2386 \pm 35$ & $2342-2493$ & \\
\hline & & $2.10-2.12$ & $\begin{array}{l}\text { Pollen } \\
\text { residue }\end{array}$ & $3853 \pm 40$ & $4215-4409$ & \\
\hline & & $2.38-2.40$ & $\begin{array}{l}\text { Pollen } \\
\text { residue }\end{array}$ & $5780 \pm 30$ & 6498-6656 & \\
\hline & & $2.42-2.44$ & $\begin{array}{l}\text { Pollen } \\
\text { residue }\end{array}$ & $5600 \pm 40$ & $6299-6453$ & \\
\hline & & $2.5-2.52$ & $\begin{array}{l}\text { Pollen } \\
\text { residue }\end{array}$ & $5114 \pm 35$ & $5749-5830$ & \\
\hline & & $2.58-2.60$ & $\begin{array}{l}\text { Pollen } \\
\text { residue }\end{array}$ & $4920 \pm 35$ & $5594-5718$ & \\
\hline
\end{tabular}




\begin{tabular}{|c|c|c|c|c|c|c|}
\hline \multirow[t]{3}{*}{ TYL } & $\begin{array}{l}31^{\circ} 11^{\prime} 54^{\prime \prime} \mathrm{N} \\
121^{\circ} 06^{\prime} 40^{\prime \prime} \mathrm{E}\end{array}$ & $1.2-1.22$ & $\begin{array}{l}\text { Pollen } \\
\text { residue }\end{array}$ & $2330 \pm 40$ & $2304-2469$ & \multirow[t]{3}{*}{$\begin{array}{c}\text { Zong et al., } \\
2012 \mathrm{~b}\end{array}$} \\
\hline & & $1.6-1.62$ & $\begin{array}{l}\text { Pollen } \\
\text { residue }\end{array}$ & $2390 \pm 40$ & $2338-2505$ & \\
\hline & & $2.0-2.02$ & $\begin{array}{l}\text { Pollen } \\
\text { residue }\end{array}$ & $3680 \pm 40$ & $3897-4096$ & \\
\hline \multirow[t]{2}{*}{ TCM } & $\begin{array}{l}31^{\circ} 01^{\prime} 48^{\prime \prime} \mathrm{N} \\
121^{\circ} 05^{\prime} 30^{\prime \prime} \mathrm{E}\end{array}$ & $1.72-1.74$ & $\begin{array}{l}\text { Pollen } \\
\text { residue }\end{array}$ & $4140 \pm 40$ & $4567-4825$ & \multirow[t]{2}{*}{$\begin{array}{l}\text { Zong et al., } \\
\quad 2011\end{array}$} \\
\hline & & $2.12-2.14$ & $\begin{array}{l}\text { Pollen } \\
\text { residue }\end{array}$ & $5230 \pm 40$ & $5912-6029$ & \\
\hline \multirow[t]{8}{*}{ GFL } & $\begin{array}{l}31^{\circ} 03^{\prime} 52^{\prime \prime} \mathrm{N} \\
121^{\circ} 11^{\prime} 30^{\prime \prime} \mathrm{E}\end{array}$ & 0.28 & I & $1070 \pm 50$ & 909-1088 & \multirow[t]{8}{*}{$\begin{array}{c}\text { Wang et al., } \\
\quad 2012\end{array}$} \\
\hline & & $0.62-0.64$ & Wood & $945 \pm 30$ & 794-925 & \\
\hline & & $0.70-0.72$ & $\begin{array}{l}\text { Pollen } \\
\text { residue }\end{array}$ & $2057 \pm 30$ & $1945-2118$ & \\
\hline & & 0.75 & I & $2710 \pm 40$ & $2752-2879$ & \\
\hline & & $0.88-0.90$ & Charcoal & $2453 \pm 30$ & $2362-2544$ & \\
\hline & & 1.00 & I & $4110 \pm 40$ & $4521-4730$ & \\
\hline & & 1.05 & I & $4600 \pm 40$ & $5346-5466$ & \\
\hline & & $1.74-1.76$ & Charcoal & $5517 \pm 55$ & $6276-6403$ & \\
\hline \multirow[t]{2}{*}{$\mathbf{T L}$} & $\begin{array}{l}30^{\circ} 53^{\prime} 12^{\prime \prime} \mathrm{N} \\
121^{\circ} 18^{\prime} 42^{\prime \prime} \mathrm{E}\end{array}$ & $2.1-2.12$ & $\begin{array}{l}\text { Pollen } \\
\text { residue }\end{array}$ & $5800 \pm 40$ & 6493-6678 & \multirow[t]{2}{*}{$\begin{array}{l}\text { Zong et al., } \\
2011\end{array}$} \\
\hline & & $2.3-2.32$ & $\begin{array}{l}\text { Pollen } \\
\text { residue }\end{array}$ & $7390 \pm 50$ & $8152-8344$ & \\
\hline
\end{tabular}

\section{References}

Atahan, P., Itzstein-Davey, F., Taylor, D., Dodson, J., Qin, J., Zheng, H., Brooks, A., 2008.

Holocene-aged sedimentary records of environmental changes and early agriculture in the lower

9 Yangtze, China. Quaternary Science Reviews 27, 556-570.

10 Chang, W.Y.B., Xu, X.M., Yang, J.R., Liu, J.L., 1994. Evolution in Taihu Lake ecosystem as

11 evidence of changes in sediment profiles. Journal of Lake Science 6, 217-226.

12 Chen, Z., Wang, Z., Schneiderman, J., Taol, J., Cail, Y., 2005. Holocene climate fluctuations in

13 the Yangtze delta of eastern China and the Neolithic response. The Holocene 15, 915-924. 
Hong, X., 1991. Origin and evolution of the Taihu Lake. Marine Geology and Quaternary Geology 11, 87-99 (in Chinese, with English abstract).

Innes, J.B., Zong, Y., Wang, Z., Chen, Z., 2014. Climatic and palaeoecological changes during the mid-to Late Holocene transition in eastern China: high-resolution pollen and non-pollen palynomorph analysis at Pingwang, Yangtze coastal lowlands. Quaternary Science Reviews 99, 164-175.

Itzstein-Davey, F., Atahan, P., Dodson, J., Taylor, D., Zheng, H., 2007. Environmental and cultural changes during the terminal Neolithic: Qingpu, Yangtze delta, eastern China. The Holocene 17, 875-887.

Liu, Y., Sun, Q., Thomas, I., Zhang, L., Finlayson, B., Zhang, W., Chen, J., Chen, Z., 2015. Middle Holocene coastal environment and the rise of the Liangzhu City complex on the Yangtze delta, China. Quaternary Research 84, 326-334.

Li, L., Zhu, C., Lin, L., Zhao, Q., Shi, G., Zhu, H., 2008. Transgression records between 7500$5400 \mathrm{BC}$ on the stratum of the Luotuodun site in Yixing, Jiangsu province. Acta Geographica Sinica 63, 1189-1197.

Qin, J., Taylor, D., Atahan, P., Zhang, X., Wu, G., Dodson, J., Zheng, H., Itzstein-Davey, F., 2011. Neolithic agriculture, freshwater resources and rapid environmental changes on the lower Yangtze, China. Quaternary Research 75, 55-65.

Tao, J., Chen, M.T., Xu, S., 2006. A Holocene environmental record from the southern Yangtze River delta, eastern China. Palaeogeography, Palaeoclimatology, Palaeoecology 230, 204-229.

Yan, Q., Huang, S., 1987. Evolution of Holocene sedimentary environment in the HangzhouJiaxing-Huzhou Plain. Acta Geographica Sinica 42, 1-15 (in Chinese, with English abstract).

Wang, J., Chen, X., Zhu, X.H., Liu, J.L., Chang, W.Y.B., 2001. Taihu Lake, lower Yangtze drainage basin: evolution, sedimentation rate and the sea level. Geomorphology 41, 183-193.

Wang, Z., Zhuang, C., Saito, Y., Chen, J., Zhan, Q., Wang, X., 2012. Early mid-Holocene sealevel change and coastal environmental response on the southern Yangtze delta plain, China: implications for the rise of Neolithic culture. Quaternary Science Reviews 35, 51-62.

Zhou, H., Zheng, X., 2000. The Impact of Environmental Changes on the Development of Prehistoric Civilization: The Decline of the Ancient Liang zhu Culture in the Southern Plain of Yangtze River Delta. Journal of East China Normal University (Natural Science) 4, 71-77 (in Chinese, with English abstract).

Zong, Y.Q., Innes, J.B., Wang, Z.H., Chen, Z.Y., 2011. Mid-Holocene coastal hydrology and salinity changes in the east Taihu area of the lower Yangtze wetlands, China. Quaternary Research 76, 69-82.

Zong, Y., Innes, J.B., Wang, Z., Chen, Z., 2012b. Environmental change and Neolithic settlement movement in the lower Yangtze wetlands of China. Holocene 22, 659-673. 